\title{
Accounting graduates and the capabilities that count: Perceptions of graduates, employers and Accounting academics in four Australian universities
}

\author{
Beverley Oliver ${ }^{1}$, Barbara Whelan ${ }^{1}$, Lynne Hunt ${ }^{2}$, Sara Hammer ${ }^{2}$ \\ b.oliver@curtin.edu.au, b.whelan@curtin.edu.au, lynne.hunt@usq.edu.au, \\ sara.hammer@usq.edu.au \\ ${ }^{1}$ Curtin University, ${ }^{2}$ University of Southern Queensland
}

\begin{abstract}
The higher education sector in Australia is moving rapidly towards greater accountability in regard to graduate employability outcomes. Currently, data on new graduates' selfreported generic skills and employment status provide the evidence base for universities to make judgements about the effectiveness of curricula in preparing students for employment. This paper discusses alternative sources of evidence, namely the Graduate Employability Indicators (GEI) - a suite of three online surveys designed to supplement current indicators. They are designed to gather and report graduate, employer and course (teaching) team perceptions of the achievement and importance of graduate capabilities within specific degree programs. In 2009 and 2010, the surveys were administered to stakeholder groups associated with Accounting degrees in four Australian universities. In total, 316 graduates, 99 employers and 51 members of the course teaching teams responded to the surveys. This report presents the aggregated results from the trial. These suggest that the fourteen capabilities at the heart of the GEI are considered important, and that both quantitative and qualitative items facilitate the reporting of essential information. Both Accounting employers and teaching staff consider that important capabilities need to be better demonstrated by new graduates. The graduates themselves identified ways in which their courses can be improved to enhance their early professional success. An importance-performance analysis suggests prioritising particular capabilities for immediate attention in particular, work related knowledge and skills, writing clearly and effectively, thinking critically and analytically, solving complex, real-world problems and developing general industry awareness. This paper suggests that an enhanced industry focus might be effected through authentic assessment tasks, and clear identification of the capabilities developed through the curriculum.
\end{abstract}

Keywords: graduate employability, capabilities, graduate, employer and faculty perspectives

\section{Acknowledgements}

The authors wish to acknowledge Ms Jane Sneesby for assistance with SPSS Text Analysis for Surveys, and Accounting colleagues $\mathrm{Dr}$ Beverley Jackling, Associate Professor Glennda Scully, Associate Professor Stacey Porter and Dr Geoff Slaughter for assistance in communicating with Accounting graduates, employers, professional bodies and course teams.

Oliver, B., Whelan, B., Hunt, L., \& Hammer, S. (2011). Accounting graduates and the capabilities that count: Perceptions of graduates, employers and Accounting academics in four Australian Universities. 


\section{Introduction}

Recent Australian publications suggest that Accounting, as a university discipline, is 'at the crossroads', and under pressure from conflicting administrative and educational requirements (Evans, 2010). The administrative pressure is due, in part, to the increased numbers of international students in Australian universities. As well as providing a source of significant revenue, such student populations also present challenges because, as graduates, they practice accounting beyond Australian shores (Lightbody, 2010). However, globalisation does mean that domestic Australian students have similar needs and require a curriculum that responds to professional accreditation processes within Australia and internationally. Tension arises from conflicting priorities in courses such as Accounting, because universities must pursue revenue sources and quality for accreditation purposes (Parker, 2010) in a highly competitive environment. In Australia, for example, competition for Accounting students has escalated with the advent of private providers. Two years after their introduction in Australia in 2006, private providers had captured a tenth of higher education students, and most were international business students (Ryan, 2010). In 2007, international students comprised $27 \%$ of the total student population and just over half were enrolled in business courses (Parker, 2010).

This growth in competition has contributed to increased emphasis on internationally recognised standards and many universities are now seeking accreditation provided by the Association for Advancement of Collegiate Schools of Business (AACSB) (Lightbody, 2010). More broadly, the advent of the Tertiary Education Quality and Standards Agency (TEQSA) means that Australian higher education providers must demonstrate that their courses meet threshold academic standards (Freeman, 2010) also expressed as threshold learning outcomes (Nicoll, 2010). Accounting was one of the first disciplines to be chosen for the development of these threshold outcomes as part of the Australian Learning and Teaching Council (ALTC) Learning and Teaching Academic Standards (LTAS) project because it has well-defined employment outcomes, professional accrediting bodies engage with the academic community, and large enrolments in public and private business higher education institutions (Freeman, 2010). These threshold learning outcomes must be measurable and promote efficient, transparent and sustainable institutional or disciplinary assessment processes without leading to standardisation of curricula or standardised tests (Freeman, 2010). This quest for accreditation and measuring standards is a challenge given the general lack of evidence: higher education providers typically draw only on indirect evidence of quality (such as student progression rates) and these are largely unconvincing as they contain no direct evidence of demonstrable competence that minimum standards have been met (Freeman, 2010).

In spite of the challenges, this move to a more transparent and evidence-based outcomes approach will continue. For example, the Australian government has recently announced that standardised testing to assure generic capabilities will be introduced in 2013 (Department of Education Employment and Workplace Relations, 2010). Further, the trend has parallels with trends in the United States (Miller \& Leskes, 2005), the United Kingdom with its Subject Benchmarks (Quality Assurance Agency, n.d.) and the Tuning process in Europe (Gonzalez \& Wagenaar, 2008).

In addition to the tensions caused by high international student enrolments and the need to address standards and quality scrutiny, there is concern that Accounting graduates lack the skills required for professional practice. Concern about their communication and generic skills were raised in 1990 in the Mathews Report which emphasised the need to integrate communication and computing skills into Accounting programs (Hancock, P., Howieson, B., Kavanagh, M., Kent, J., Tempone, I., and Segal, N., 2010). More recently,

Oliver, B., Whelan, B., Hunt, L., \& Hammer, S. (2011). Accounting graduates and the capabilities that count: Perceptions of graduates, employers and Accounting academics in four Australian Universities. 
the ALTC Accounting for the Future project interrogated the changing Accounting graduate skill requirements and investigated non-technical skills (referred to henceforth as generic capabilities) such as communication, interpersonal and critical thinking skills required over the next 10 years (Hancock et al., 2010). Through interviews with 47 employers from a range of organisations, the project team sifted the broad skill categories most frequently referred to by interviewees. They were: communication and presentation; teamwork and good interpersonal skills; self-management; initiative and enterprise; problem solving; technological competence; and planning and organising skills (Hancock et al., 2010). These generic capabilities - particularly communication, teamwork, problem solving, selfmanagement and interpersonal skills-emerged as the discriminators for professional success: Hancock found that when employers had to choose between applicants of similar academic ability, they chose the applicant who displayed strength in these generic capabilities (Hancock et al., 2010). Results from the study indicated that concerns about Australian graduates' generic capabilities were focused on the higher order skills, such as "analytical and critical analysis, and the ability to engage clients, negotiate and act strategically" (Hancock et al., 2010, p. 54).

Faced with these findings, higher education providers need to assure that their graduates have acquired generic capabilities. Unfortunately, measurement of such capabilities through standardised tests such as the Graduate Skills Assessment Test (Australian Council for Educational Research, 2005) or the Collegiate Learning Assessment is highly contested (Association of American Colleges and Universities, 2005, 2007). One solution is to extend data to incorporate perceptions of success. Currently, Australian universities capture graduates' perceptions by drawing on the Course Experience Questionnaire (CEQ) as part of the Australian Graduate Survey. The CEQ Generic Skills Scale items gather responses from graduates about four months after they have completed their degree programs. The items for their consideration are:

1. The course helped me develop my ability to work as a team member

2. The course sharpened my analytic skills

3. The course developed my problem solving skills

4. The course improved my skills in written communication

5. As a result of my course, I feel confident about tackling unfamiliar problems

6. My course helped me to develop the ability to plan my own work

The CEQ is validated and widely researched and used across Australia, and derivations have been used elsewhere (Ainley \& Johnson, 2000; Mclnnis, Griffin, James, \& Coates, 2001; Ramsden, 1999; Richardson, 2005). However, the generic capabilities incorporated into these items do not have a specific employability focus, although many overlap with commonly accepted employment-related skills. Recent research has suggested that although graduates might rate their generic capabilities, the focus on their future profession is commonly lacking. The recent findings of the Australian Survey of Student Engagement, for example, reveal that many undergraduates feel ill equipped to enter the workforce and more than a third leave university without an up-to-date résumé (Milburn, 2010). Course Experience Questionnaire respondents are graduates who are often either very new to employment in their profession, or they have not yet secured such employment. In addition, self-reported perceptions such as those generated from the CEQ items are not calibrated against others' perceptions, such as employers and faculty. Perceptions of employers and academic teaching staff on what graduates need to succeed, and whether graduates generally demonstrate the 'capabilities that count' is not systematically collected in Australia, nor is there any routine collection of teaching staff perceptions about their confidence in teaching and assessing these generic capabilities. The CEQ, therefore, has little relevance to employability or curriculum issues, nor does the

Oliver, B., Whelan, B., Hunt, L., \& Hammer, S. (2011). Accounting graduates and the capabilities that count: Perceptions of graduates, employers and Accounting academics in four Australian Universities. 
other oft-used indicator, the Graduate Destination Survey: figures reporting employment are subject to labour market forces, and do not capture information about whether the expectations of new graduates (their own career prospects, or the views of their employers) are being met.

\section{Introducing the Graduate Employability Indicators}

The ALTC Competitive Grant, Building course team capacity to enhance graduate employability, has sought to address the data gaps inherent in current measures associated with employability skills through the development of the Graduate Employability Indicators (GEI), a suite of three online surveys which focus on fourteen capabilities and gather the perceptions of:

- Graduates of up to five years:

0 the extent to which the course contributed to their achievement of the capabilities;

- the importance of the capabilities to early professional success.

- Employers:

○ the extent to which graduates generally demonstrate the capabilities;

○ the importance of the capabilities to graduates' early professional success.

- Faculty who teach the course (the course team):

○ the extent to which graduates generally demonstrate the capabilities;

- the importance of the capabilities to graduates' early professional success;

$\circ$ their confidence in teaching and assessing the capabilities.

Each stakeholder group is also asked to report their perception of graduates' overall workreadiness. The GEI provide evidence to answer the following questions in relation to generic capability achievement within a specific degree program:

1. How important are the fourteen capabilities for early professional success to graduates of this course?

2. To what extent do graduates generally demonstrate the capabilities (according to employers and course team), or do courses contribute to their development (according to graduates)?

3. To what extent are graduates perceived as work-ready?

4. How confident are course teams in teaching and assessing the capabilities?

The importance of this broader approach to measurement is that data can be used to improve curricula focused on the capabilities that count most to:

- ensure that key capabilities are contextualised, embedded and assessed developmentally throughout the course, and recognisably so by graduates;

- have employers and course teams perceive that the capabilities that count are demonstrated by graduates; and

- ensure that course teams are confident in teaching and assessing the capabilities that count for employment success.

\section{Which capabilities?}

A widely-accepted definition of graduate employability is the achievement of the skills, understandings and personal attributes that make an individual more likely to secure employment and be successful in their chosen occupations to the benefit of themselves, the workforce, the community and the economy' (Yorke, 2006). One of the challenges in designing the GEI was to decide which capabilities to include, knowing that no instrument 
could include everything which might be perceived as important, that there are multiple and competing lists of capabilities, and that graduate attributes and their attainment do not always correlate with employability. The term 'capabilities' is not widely used in Australia, however, as defined by Stephenson (1998) it connotes lifelong learning, integration, and the confidence to realise future potential in a developmental and self-managed way. This definition gels with the widely-agreed aims of university education, as well as Yorke's definition of graduate employability (Yorke, 2006). "Capable people," according to Stephenson, "have confidence in their ability to take effective and appropriate action, explain what they are seeking to achieve, live and work effectively with others, and continue to learn from their experiences, both as individuals and in association with others, in a diverse and changing society" (Stephenson, 1998, p.2).

Research in Australia shows that there is no single list that incorporates the capabilities, or what most universities call graduate attributes (Barrie, Hughes, \& Smith, 2009). They are often a mix of generic skills, employability skills and aspects of civic engagement. International lists of competencies are similarly mixed. For example, the Essential Learning Outcomes are the source of many institutions' goals in the United States (Association of American Colleges and Universities, 2004); European research through the Tuning Process gathered stakeholder perceptions of a set of competences (Villa, González, Auzmendi, Beza-nilla, \& Laka, 2008). Studies in employability in the United Kingdom draw on a range of capabilities, such as those in the Knight and Yorke USEM model (Knight \& Yorke, 2004). A scan of such lists suggests that, in spite of various terms used, most lists include capabilities that cluster around communication, thinking skills, teamwork, self-management and civic engagement.

For the GEI, a 'one size fits most' list was needed so that higher education institutions could draw on named capabilities to focus on particular attributes as well as professional accreditation competencies. The decision was made to draw such a list from previously validated surveys: the fourteen capabilities in the GEI were drawn from one item in the Graduate Pathways Survey (Coates \& Edwards, 2009) which, in turn was based on Item 12 in the Australian University Survey of Student Engagement (AUSSE) (Coates, 2009) and Item 11 in the National Survey of Student Engagement (NSSE) widely used in the United States (Kuh, 2001). All three surveys included an item asking respondents 'To what extent has your experience at this institution contributed to your knowledge, skills and personal development in the following areas?' Because of its employability focus, the GEI also gathers perceptions of graduates' overall work-readiness. The response categories in the GEI mirror those in the surveys on which they are based (Very little; Some; Quite a bit; Very much).

The GEl asks graduates of up to five years to what extent their course experience contributed to their knowledge, skills and personal development: to enable triangulation with other stakeholders, the GEI asks the same of employers and course teams 'To what extent do new graduates generally demonstrate each of the following?' In addition, and drawing on the recommendation of Scott et al. (Scott, 2005), the GEI also asks each stakeholder group their perceptions about importance 'How important do you think each of the following is to the employment success of new graduates of this degree?' In other words, the GEl ask 'what are the capabilities that count (importance), and to what extent are they generally demonstrated by graduates (according to employers and teaching staff), or developed in courses (according to graduates)? In addition, and to inform the professional development needs of university teaching staff, the GEI also asks course teams to indicate their confidence in teaching and assessing the capabilities (see Table 1). All stakeholder groups are also asked a limited number of qualitative items most of which focus on strengths (that is, capabilities that are clearly demonstrated), challenges (that is, capabilities that need improvement) and overall comment, as shown in detail in Table 2.

Oliver, B., Whelan, B., Hunt, L., \& Hammer, S. (2011). Accounting graduates and the capabilities that count: Perceptions of graduates, employers and Accounting academics in four Australian Universities. 
Table 1: Summary of stakeholder groups and quantitative items of the Graduate Employability Indicators and the surveys from which the items are derived

\begin{tabular}{|c|c|c|c|c|c|c|}
\hline Instrument & NSSE 2007 & AUSSE 2008 & GPS 2008 & $\begin{array}{l}\text { Graduate Employability } \\
\text { Indicators }\end{array}$ & $\begin{array}{l}\text { Graduate Employability } \\
\text { Indicators }\end{array}$ & $\begin{array}{l}\text { Graduate Employability } \\
\text { Indicators }\end{array}$ \\
\hline Stakeholders & Students & Students & Graduates (five years only) & Graduates (up to five years) & Employers & Course team \\
\hline \multirow[t]{4}{*}{ Quantitative Items } & $\begin{array}{l}\text { 1. To what extent has your } \\
\text { experience at this institution } \\
\text { contributed to your knowledge, } \\
\text { skills, and personal } \\
\text { development in the following } \\
\text { areas? }\end{array}$ & $\begin{array}{l}\text { 1. To what extent has your } \\
\text { experience at this institution } \\
\text { contributed to your knowledge, } \\
\text { skills and personal development } \\
\text { in the following areas? }\end{array}$ & $\begin{array}{l}\text { 1. To what extent did your } \\
\text { experience during your bachelor } \\
\text { degree(s) contribute to your } \\
\text { knowledge, skills and personal } \\
\text { development in the following } \\
\text { areas? }\end{array}$ & $\begin{array}{l}\text { 1. To what extent did your } \\
\text { experience during this degree } \\
\text { contribute to your development } \\
\text { in the following areas? }\end{array}$ & $\begin{array}{l}\text { 1. To what extent do new } \\
\text { graduates generally } \\
\text { demonstrate each of the } \\
\text { following? }\end{array}$ & $\begin{array}{l}\text { 1. To what extent do new } \\
\text { graduates generally } \\
\text { demonstrate each of the } \\
\text { following? }\end{array}$ \\
\hline & & & & $\begin{array}{l}\text { 2. How important do you think } \\
\text { each of the following is to the } \\
\text { employment success of new } \\
\text { graduates of this degree? }\end{array}$ & $\begin{array}{l}\text { 2. How important do you think } \\
\text { each of the following is to the } \\
\text { employment success of new } \\
\text { graduates of this degree? }\end{array}$ & $\begin{array}{l}\text { 2. How important do you think } \\
\text { each of the following is to the } \\
\text { employment success of new } \\
\text { graduates of this degree? }\end{array}$ \\
\hline & & & & & & $\begin{array}{l}\text { 3. How confident are you in } \\
\text { teaching each of the following? }\end{array}$ \\
\hline & & & & & & $\begin{array}{l}\text { 4. How confident are you in } \\
\text { assessing each of the following? }\end{array}$ \\
\hline \multicolumn{7}{|l|}{ ‘Capabilities' } \\
\hline Acquiring a broad general education & $\sqrt{ }$ & $\sqrt{ }$ & & & & \\
\hline Acquiring work-related knowledge/skills & $\sqrt{ }$ & $\checkmark$ & $\checkmark$ & $\sqrt{ }$ & $\sqrt{ }$ & $\sqrt{ }$ \\
\hline Writing clearly and effectively & $\sqrt{ }$ & $\sqrt{ }$ & $\sqrt{ }$ & $\sqrt{ }$ & $\sqrt{ }$ & $\sqrt{ }$ \\
\hline Speaking clearly and effectively & $\sqrt{ }$ & $\checkmark$ & $\sqrt{ }$ & $\sqrt{ }$ & $\sqrt{ }$ & $\sqrt{ }$ \\
\hline Thinking critically and analytically & $\sqrt{ }$ & $\sqrt{ }$ & $\sqrt{ }$ & $\sqrt{ }$ & $\sqrt{ }$ & $\sqrt{ }$ \\
\hline Analysing quantitative problems & $\sqrt{ }$ & $\checkmark$ & $\sqrt{ }$ & $\sqrt{ }$ & $\sqrt{ }$ & $\sqrt{ }$ \\
\hline Using ICT & $\checkmark$ & $\sqrt{ }$ & $\checkmark$ & $\sqrt{ }$ & $\checkmark$ & $\sqrt{ }$ \\
\hline Working effectively with others & $\sqrt{ }$ & $\sqrt{ }$ & $\sqrt{ }$ & $\sqrt{ }$ & $\sqrt{ }$ & $\sqrt{ }$ \\
\hline Voting in local, state, or national elections & $\sqrt{ }$ & $\sqrt{ }$ & & & & \\
\hline Learning effectively on your own & $\sqrt{ }$ & $\sqrt{ }$ & $\sqrt{ }$ & $\sqrt{ }$ & $\sqrt{ }$ & $\sqrt{ }$ \\
\hline Understanding yourself & $\checkmark$ & $\sqrt{ }$ & & & & \\
\hline $\begin{array}{l}\text { Understanding people of other racial and } \\
\text { ethnic backgrounds }\end{array}$ & $\checkmark$ & $\sqrt{ }$ & $\checkmark$ & $\checkmark$ & $\checkmark$ & $\checkmark$ \\
\hline Solving complex real-world problems & $\sqrt{ }$ & $\sqrt{ }$ & $\sqrt{ }$ & $\sqrt{ }$ & $\sqrt{ }$ & $\checkmark$ \\
\hline Developing personal code of values/ethics & $\sqrt{ }$ & $\sqrt{ }$ & $\checkmark$ & $\sqrt{ }$ & $\checkmark$ & $\checkmark$ \\
\hline Contributing to welfare of your community & $\sqrt{ }$ & $\sqrt{ }$ & $\sqrt{ }$ & $\sqrt{ }$ & $\sqrt{ }$ & $\sqrt{ }$ \\
\hline Developing deepened sense of spirituality & & $\sqrt{ }$ & $\sqrt{ }$ & $\sqrt{ }$ & $\checkmark$ & $\sqrt{ }$ \\
\hline Understanding different social contexts & & & $\sqrt{ }$ & $\sqrt{ }$ & $\sqrt{ }$ & $\sqrt{ }$ \\
\hline
\end{tabular}

Oliver, B., Whelan, B., Hunt, L., \& Hammer, S. (2011). Accounting graduates and the capabilities that count: Perceptions of graduates, employers and Accounting academics in four Australian

Universities. 
Table 2: Summary of stakeholder groups and qualitative items of the Graduate Employability Indicators and the surveys from which the items are derived

\begin{tabular}{|c|c|c|c|c|c|c|}
\hline Instrument & NSSE 2007 & AUSSE 2008 & GPS 2008 & $\begin{array}{l}\text { Graduate Employability } \\
\text { Indicators }\end{array}$ & $\begin{array}{l}\text { Graduate Employability } \\
\text { Indicators }\end{array}$ & $\begin{array}{l}\text { Graduate Employability } \\
\text { Indicators }\end{array}$ \\
\hline Stakeholders & Students & Students & $\begin{array}{l}\text { Graduates (five years } \\
\text { only) }\end{array}$ & $\begin{array}{l}\text { Graduates (up to five } \\
\text { years) }\end{array}$ & Employers & Course team \\
\hline \multirow{4}{*}{$\begin{array}{l}\text { Qualitative } \\
\text { items }\end{array}$} & \multirow{4}{*}{ Nil } & \multirow{4}{*}{ Nil } & \multirow{4}{*}{ Nil } & $\begin{array}{l}\text { What were the best } \\
\text { aspects of this degree in } \\
\text { developing your skills for } \\
\text { employment? }\end{array}$ & $\begin{array}{l}\text { What skills, attributes and } \\
\text { personal qualities do you } \\
\text { consider to be the most } \\
\text { useful for new graduates } \\
\text { in this field? }\end{array}$ & $\begin{array}{l}\text { What do you see as the } \\
\text { main incentives for } \\
\text { teaching staff to assist } \\
\text { students to develop work- } \\
\text { related skills, attributes } \\
\text { and personal qualities?' }\end{array}$ \\
\hline & & & & $\begin{array}{l}\text { How could the degree be } \\
\text { changed to improve your } \\
\text { skills for employment? }\end{array}$ & $\begin{array}{l}\text { Which (if any) skills, } \\
\text { attributes and personal } \\
\text { qualities of new graduate } \\
\text { attributes would you } \\
\text { prioritise for improvement? }\end{array}$ & $\begin{array}{l}\text { What do you see as the } \\
\text { main disincentives for } \\
\text { teaching staff to assist } \\
\text { students to develop work- } \\
\text { related skills, attributes } \\
\text { and personal qualities? }\end{array}$ \\
\hline & & & & & & $\begin{array}{l}\text { What do you see as your } \\
\text { role in assisting students } \\
\text { to develop these } \\
\text { attributes, skills and } \\
\text { personal qualities? }\end{array}$ \\
\hline & & & & & & $\begin{array}{l}\text { What sort of staff } \\
\text { development opportunities } \\
\text { would increase your } \\
\text { confidence to teach and } \\
\text { assess work-related skills, } \\
\text { attributes and personal } \\
\text { qualities? }\end{array}$ \\
\hline
\end{tabular}

Oliver, B., Whelan, B., Hunt, L., \& Hammer, S. (2011). Accounting graduates and the capabilities that count: Perceptions of graduates, employers and Accounting academics in four Australian Universities. 
For the purpose of brevity in graphing results, the 14 capabilities in the GEI are frequently referred to with abbreviated titles, as shown in Table 3 . Full text of the capabilities is used in the interpretation of results. Also shown in Table 3 is a summary of the quantitative items asked of each stakeholder group in the GEl.

Table 3: The abbreviated titles of the fourteen capabilities in the Graduate Employability Indicators and a summary of the quantitative items asked of the stakeholder groups

\begin{tabular}{|c|c|c|c|c|c|c|c|c|c|}
\hline \multicolumn{2}{|c|}{ Capabilities } & \multicolumn{2}{|c|}{ Graduates } & \multicolumn{2}{|c|}{ Employers } & \multicolumn{4}{|c|}{ Course team } \\
\hline $\begin{array}{l}\text { Abbreviated } \\
\text { title }\end{array}$ & Full text in survey & 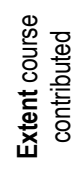 & 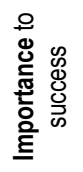 & 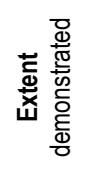 & 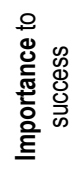 & 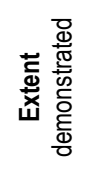 & 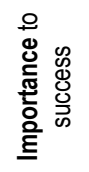 & 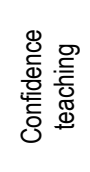 & 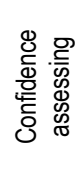 \\
\hline 1. Knowledge & $\begin{array}{l}\text { Work related } \\
\text { knowledge and skills }\end{array}$ & & & & & & & & \\
\hline 2. Writing & $\begin{array}{l}\text { Writing clearly and } \\
\text { effectively }\end{array}$ & & & & & & & & \\
\hline 3. Speaking & $\begin{array}{l}\text { Speaking clearly and } \\
\text { effectively }\end{array}$ & & & & & & & & \\
\hline 4. Thinking & $\begin{array}{l}\text { Thinking critically and } \\
\text { analytically }\end{array}$ & & & & & & & & \\
\hline 5. Quantitative & $\begin{array}{l}\text { Analysing quantitative } \\
\text { problems }\end{array}$ & & & & & & & & \\
\hline 6. Using ICT & $\begin{array}{l}\text { Using computing and } \\
\text { information technology }\end{array}$ & & & & & & & & \\
\hline 7. Teamwork & $\begin{array}{l}\text { Working effectively } \\
\text { with others }\end{array}$ & & & & & & & & \\
\hline $\begin{array}{l}\text { 8. Independent } \\
\text { Learning }\end{array}$ & $\begin{array}{l}\text { Learning effectively on } \\
\text { your own }\end{array}$ & & & & & & & & \\
\hline $\begin{array}{l}\text { 9. Intercultural } \\
\text { Understanding }\end{array}$ & $\begin{array}{l}\text { Understanding people } \\
\text { of other racial and } \\
\text { ethnic backgrounds }\end{array}$ & & & & & & & & \\
\hline $\begin{array}{l}\text { 10. Problem- } \\
\text { solving }\end{array}$ & $\begin{array}{l}\text { Solving complex, real- } \\
\text { world problems }\end{array}$ & & & & & & & & \\
\hline $\begin{array}{l}\text { 11. Values \& } \\
\text { Ethics }\end{array}$ & $\begin{array}{l}\text { Developing a personal } \\
\text { code of values and } \\
\text { ethics }\end{array}$ & & & & & & & & \\
\hline $\begin{array}{l}\text { 12. Community } \\
\text { Engagement }\end{array}$ & $\begin{array}{l}\text { Contributing to the } \\
\text { welfare of your } \\
\text { community }\end{array}$ & & & & & & & & \\
\hline $\begin{array}{l}\text { 13. Industry } \\
\text { awareness }\end{array}$ & $\begin{array}{l}\text { Developing general } \\
\text { industry awareness }\end{array}$ & & & & & & & & \\
\hline $\begin{array}{l}\text { 14. Social } \\
\text { contexts }\end{array}$ & $\begin{array}{l}\text { Understanding } \\
\text { different social } \\
\text { contexts }\end{array}$ & & & & & & & & \\
\hline
\end{tabular}

\section{Method}

The Building course team capacity to enhance graduate employability project administered the GEI graduates, employers, and course teams-in the four partner universities between 2009 and 2010. Details of the administration of the survey have been reported elsewhere (Whelan, B., Oliver, B., Hunt, L., Hammer, S., Jones, S., and Pearce, A., 2010). The GEI was administered online through a Curtin University website and direct links to the surveys were provided to the stakeholder groups. Accounting graduates from Curtin were contacted in October 2009, and the remaining stakeholder groups were contacted in 2010. Data were collated in June 2010, part way through the data collection, and used to draw up preliminary reports for members of the course teams. These reports were useful for getting more buy-in

Oliver, B., Whelan, B., Hunt, L., \& Hammer, S. (2011). Accounting graduates and the capabilities that count: Perceptions of graduates, employers and Accounting academics in four Australian Universities. 
from busy course leaders, as the preliminary results demonstrated their applicability and relevance. The surveys were closed in October 2010 and a final report was provided to each university showing the results only for their own courses, as well as an overview of the total pool (that is an aggregation of all responses collected in connection with the four Accounting courses).

\section{Responses}

Accounting graduates were quite responsive to the surveys. They were contacted directly by their respective university alumni office and reminders were sent out prior to closure of the survey period to encourage responses. In total, 316 of the 1332 graduates contacted from the four universities responded to the surveys. This represents a response rate of $23.7 \%$ (although it is not possible to calculate a definitive response rate because the number of 'live' email addresses in the various alumni databases is unknown; anecdotal evidence suggests many are no longer in use). Thirty seven percent of all respondents were from Curtin University, 34\% from University of Southern Queensland, 11\% from RMIT University and 18\% from Victoria University. The graduate respondent group was predominantly female $(62 \%), 35$ years or younger $(85 \%)$ in their first three years since graduation $(72 \%)$, attending classes on campus rather than by distance education (74\%), and in Australia (72\%) rather than offshore. Just over half identified as international students (53\%). At the time of the survey, $260(82 \%)$ indicated they were employed (72\% fulltime; $10 \%$ part-time). Of those who said they were employed, $83 \%$ indicated their current employment was specifically linked to their degree; about half $(53 \%)$ indicated they were working in Australia or New Zealand and about a quarter (27\%) were working in Asia. Of those who said they were not employed, 17 graduates indicated that they had worked in an area related to their Accounting degree, and 36 graduates said they had not.

Employers were more challenging to engage than students, as institutions rarely have a coordinated approach to contacting employers and employer contacts had to be collated from several different sources (Whelan et al., 2010). Employer lists were collated by project partners from contacts held by individual academics, careers centre contacts, external relations, external body websites, career websites, Seek advertisements, Google searches and internal employers, for example, the university's own corporate financial department. For the purposes of this project, the term employer was interpreted more broadly as anyone who had or would employ a 'new' Accounting graduate from any institution, rather than just those who had employed graduates from the partner universities. Responses from invitees were at first slow, but two particular initiatives prompted rapid increases: one university's Dean of Business emailed members of the National Institute of Accountants (NIA), and on a separate occasion, the project team at another partner university attended a local branch meeting of the Certified Practicing Accountants (CPA) Australia and invited attendees to complete the survey on paper. In total, 99 employers of the 152 invited to complete the survey responded, a response rate of $65 \%$. The respondents were predominantly male (67\%) and held a variety of positions: $52 \%$ indicated they were executive or middle managers and a further $21 \%$ indicated they were owners of a small to medium enterprise. About half their organizations were small to medium enterprises (54\%) and the remainder were divided between public sector and large private sector enterprise, with the vast majority in Australia and New Zealand (91\%). The sectors in which they worked were varied, with the largest groups working in Finance and Insurance (29\%), Property and Business Services (15\%), Personal and Other Services (12\%).

Oliver, B., Whelan, B., Hunt, L., \& Hammer, S. (2011). Accounting graduates and the capabilities that count: Perceptions of graduates, employers and Accounting academics in four Australian Universities. 
The most challenging group to engage were course teams. Desktop analysis of the four universities' websites suggested that, in total, these four departments employed 263 teaching staff for their undergraduate Accounting program, including part-time and casual staff. Prior to the administration of the surveys, each partner project team met with course leaders to engage them in the project. Leaders then invited teaching staff to participate, but responses were slow. At one institution staff members were invited to fill in paper copies during a staff meeting. In total, 51 members of course teams responded to the survey. This was a response rate of $19 \%$ of the total staff as reported on their websites. The course team respondents were predominantly male (59\%), employed as full-time continuing staff $(78 \%)$ and had more than 7 years' university teaching experience (71\%). Two thirds indicated that during their career, they had been in full-time or part-time employment, research or consultancy in industries related to Accounting for more than 5 years. Others reported less than 5 years industry experience. Unsurprisingly, given the proportion of long-term staff who responded, two thirds indicated that their most recent industry experience was between 6 and 10 years ago. However, a quarter had worked, researched or consulted in industry in the past year.

\section{Quantitative Results}

The responses for the four partners were downloaded and aggregated into one Excel worksheet. Table 4 shows the percentage agreement for each response category for each quantitative item. Table 5 shows the same data summarised as 'more' or 'less' importance or extent (that is, responses for 'Quite a bit' and 'Very much' are combined and reported as 'More'; responses for 'Very little' and 'Some' are combined and reported as 'Less'). Particular opportunities for improvement lie in identifying where the capabilities that count most are reported as demonstrated least: that is, capabilities shaded both green and orange suggest potential threats to graduate employability: that is, a capability 'that really counts' is also a capability demonstrated very little or to some extent. Moreover, if this perception is common to two or three stakeholder groups, then the urgency to focus on improving that graduate capability is heightened (in the tables which follow, gold indicates where at least two stakeholder groups report similar perceptions of high importance and low demonstration). The results are also colour coded in Table 5 for easy visual analysis:

- Strengths: \% agreement that a capability is MORE important or demonstrated ('quite a bit or very much', green shading)

- Challenges: \% agreement that a capability is LESS important or demonstrated ('quite a bit or very much', orange shading)

\section{Overview of quantitative responses}

Results in Table 5 suggest that most of the fourteen capabilities are considered 'more important' to early professional success by most stakeholder groups, the exception being Contributing to the welfare of your community. The capabilities rated more important by most groups are Work-related knowledge and skills (employers rate this less important than the others), Writing and speaking clearly and effectively, Working effectively with others, Learning effectively on your own, Using computing and information technology and Developing a personal code of values and ethics. Of those capabilities rated more important, only Using computing and information technology is perceived by employers and course teams as demonstrated to a higher extent. 
A scan of the table suggests that employers and, to a lesser degree, course teams perceive that the following capabilities are demonstrated less by graduates: Solving complex, real-world problems, Contributing to the welfare of your community, Developing general industry awareness and Understanding different social contexts. There was slightly lower emphasis on the lack of demonstration of Work related knowledge and skills, Writing clearly and effectively, Thinking critically and analytically and Analysing quantitative problems. Opportunities for greatest improvement (gold shading) might arise from focusing on capabilities perceived as MORE important, and LESS demonstrated by at least two stakeholder groups:

- Work related knowledge and skills

- Writing clearly and effectively

- Thinking critically and analytically

- Solving complex, real-world problems

- Developing general industry awareness

- Understanding different social contexts

Course teams report more confidence in teaching and assessing all of the above capabilities, with the exception of Understanding different social contexts. 
Table 4: Accounting graduate, employer and course team perceptions (percentage agreement for all response categories) of (1) the extent the fourteen capabilities are developed or demonstrated; (2) their importance to early professional success; and (3) course team confidence in teaching and assessing them; as well as perceptions of overall work-readiness.

\begin{tabular}{|c|c|c|c|c|c|c|c|c|}
\hline & \multicolumn{8}{|c|}{ Graduate perceptions $(n=316)$} \\
\hline & \multicolumn{4}{|c|}{$\begin{array}{l}\text { Extent degree } \\
\text { contributed }\end{array}$} & \multicolumn{4}{|c|}{ Importance to success } \\
\hline & \multicolumn{2}{|c|}{ Less } & \multicolumn{2}{|c|}{ More } & \multicolumn{2}{|c|}{ Less } & \multicolumn{2}{|c|}{ More } \\
\hline Capability & 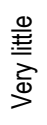 & $\stackrel{\mathscr{E}}{\mathscr{E}}$ & 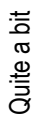 & $\begin{array}{l}\frac{c}{\mathrm{O}} \\
\stackrel{\mathrm{E}}{\mathrm{E}} \\
\stackrel{\vec{d}}{>}\end{array}$ & 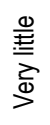 & 胥 & 离 & $\stackrel{\vec{d}}{>}$ \\
\hline 1. Knowledge & 7 & 32 & 36 & 21 & 2 & 9 & 34 & 47 \\
\hline 2. Writing & 4 & 26 & 41 & 24 & 2 & 13 & 39 & 40 \\
\hline 3. Speaking & 13 & 27 & 34 & 22 & 1 & 11 & 31 & 48 \\
\hline 4. Thinking & 3 & 22 & 45 & 26 & 1 & 6 & 31 & 54 \\
\hline 5. Quantitative & 3 & 19 & 52 & 21 & 2 & 11 & 37 & 42 \\
\hline 6. Using ICT & 5 & 22 & 41 & 27 & 1 & 10 & 31 & 51 \\
\hline 7. Teamwork & 9 & 26 & 38 & 22 & 1 & 9 & 37 & 44 \\
\hline $\begin{array}{l}\text { 8. Independent } \\
\text { learning }\end{array}$ & 2 & 16 & 40 & 37 & 1 & 14 & 36 & 35 \\
\hline $\begin{array}{l}\text { 9. Intercultural } \\
\text { understanding }\end{array}$ & 17 & 27 & 33 & 19 & 6 & 26 & 34 & 26 \\
\hline $\begin{array}{l}\text { 10. Problem- } \\
\text { solving }\end{array}$ & 13 & 34 & 34 & 13 & 2 & 9 & 38 & 43 \\
\hline $\begin{array}{l}\text { 11. Values \& } \\
\text { ethics }\end{array}$ & 9 & 33 & 35 & 19 & 3 & 16 & 40 & 34 \\
\hline $\begin{array}{l}\text { 12. Community } \\
\text { engagement }\end{array}$ & 25 & 34 & 24 & 12 & 9 & 32 & 34 & 18 \\
\hline $\begin{array}{l}\text { 13. Industry } \\
\text { awareness }\end{array}$ & 9 & 30 & 39 & 15 & 3 & 17 & 41 & 29 \\
\hline $\begin{array}{l}\text { 14. Social } \\
\text { contexts }\end{array}$ & 16 & 35 & 33 & 10 & 5 & 30 & 36 & 20 \\
\hline
\end{tabular}

\begin{tabular}{|c|c|c|c|c|c|c|c|}
\hline \multicolumn{8}{|c|}{ Employer perceptions $(n=99)$} \\
\hline \multicolumn{4}{|c|}{$\begin{array}{c}\text { Extent } \\
\text { demonstrated }\end{array}$} & \multicolumn{4}{|c|}{ Importance to success } \\
\hline \multicolumn{2}{|c|}{ Less } & \multicolumn{2}{|c|}{ More } & \multicolumn{2}{|c|}{ Less } & \multicolumn{2}{|c|}{ More } \\
\hline 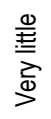 & 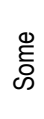 & 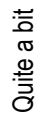 & 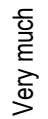 & 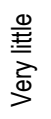 & $\begin{array}{l}\stackrel{D}{E} \\
\text { के }\end{array}$ & 訔 & $\frac{\vec{d}}{\infty}$ \\
\hline 23 & 47 & 27 & 2 & 1 & 25 & 44 & 26 \\
\hline 17 & 56 & 21 & 6 & 0 & 9 & 41 & 46 \\
\hline 10 & 47 & 36 & 6 & 0 & 2 & 40 & 54 \\
\hline 18 & 48 & 26 & 7 & 0 & 8 & 41 & 46 \\
\hline 11 & 54 & 31 & 4 & 0 & 12 & 61 & 24 \\
\hline 0 & 9 & 58 & 32 & 0 & 8 & 55 & 33 \\
\hline 5 & 44 & 43 & 6 & 0 & 5 & 36 & 55 \\
\hline 17 & 40 & 34 & 8 & 2 & 12 & 42 & 39 \\
\hline 12 & 45 & 34 & 8 & 6 & 27 & 38 & 25 \\
\hline 32 & 56 & 9 & 3 & 3 & 24 & 42 & 27 \\
\hline 6 & 51 & 34 & 8 & 1 & 8 & 40 & 47 \\
\hline 25 & 57 & 13 & 4 & 10 & 36 & 39 & 10 \\
\hline 26 & 54 & 18 & 2 & 3 & 27 & 47 & 19 \\
\hline 19 & 58 & 20 & 2 & 7 & 29 & 46 & 14 \\
\hline
\end{tabular}

\begin{tabular}{|c|c|c|c|c|c|c|c|c|c|c|c|c|c|c|c|}
\hline \multicolumn{16}{|c|}{ Course team perceptions $(n=51)$} \\
\hline \multicolumn{4}{|c|}{$\begin{array}{c}\text { Extent } \\
\text { demonstrated }\end{array}$} & \multicolumn{4}{|c|}{ Importance to success } & \multicolumn{4}{|c|}{$\begin{array}{l}\text { Confidence } \\
\text { teaching }\end{array}$} & \multicolumn{4}{|c|}{$\begin{array}{c}\text { Confidence } \\
\text { assessing }\end{array}$} \\
\hline \multicolumn{2}{|c|}{ Less } & \multicolumn{2}{|c|}{ More } & \multicolumn{2}{|c|}{ Less } & \multicolumn{2}{|c|}{ More } & \multicolumn{2}{|c|}{ Less } & \multicolumn{2}{|c|}{ More } & \multicolumn{2}{|c|}{ Less } & \multicolumn{2}{|c|}{ More } \\
\hline 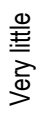 & $\begin{array}{l}\mathscr{E} \\
\stackrel{\tilde{D}}{ }\end{array}$ & 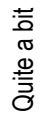 & 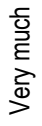 & 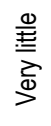 & 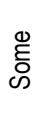 & 高 & $\stackrel{\frac{2}{d}}{>}$ & 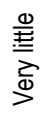 & 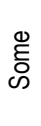 & $\stackrel{\frac{9}{7}}{\frac{0}{\circ}}$ & $\frac{\overrightarrow{0}}{\dot{p}}$ & 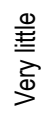 & $\begin{array}{l}\stackrel{0}{ \pm} \\
\text { हैं }\end{array}$ & 产 & 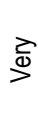 \\
\hline 16 & 53 & 18 & 8 & 0 & 10 & 45 & 43 & 0 & 12 & 41 & 45 & 0 & 14 & 43 & 43 \\
\hline 12 & 53 & 29 & 0 & 0 & 2 & 29 & 67 & 4 & 14 & 37 & 43 & 4 & 10 & 37 & 47 \\
\hline 8 & 37 & 45 & 2 & 0 & 0 & 22 & 75 & 2 & 14 & 39 & 43 & 2 & 12 & 41 & 43 \\
\hline 24 & 41 & 24 & 6 & 0 & 2 & 37 & 57 & 0 & 6 & 45 & 47 & 0 & 10 & 43 & 45 \\
\hline 12 & 27 & 43 & 12 & 0 & 6 & 55 & 37 & 2 & 4 & 35 & 57 & 0 & 10 & 27 & 61 \\
\hline 0 & 14 & 55 & 25 & 0 & 6 & 49 & 43 & 0 & 18 & 41 & 39 & 0 & 16 & 43 & 39 \\
\hline 4 & 47 & 33 & 10 & 0 & 4 & 18 & 76 & 0 & 14 & 41 & 43 & 6 & 22 & 39 & 31 \\
\hline 10 & 35 & 37 & 12 & 0 & 10 & 41 & 47 & 0 & 14 & 43 & 41 & 6 & 20 & 37 & 33 \\
\hline 10 & 37 & 33 & 14 & 0 & 20 & 43 & 35 & 0 & 22 & 35 & 39 & 8 & 22 & 41 & 27 \\
\hline 29 & 39 & 24 & 2 & 2 & 12 & 43 & 41 & 2 & 12 & 45 & 39 & 0 & 18 & 43 & 37 \\
\hline 12 & 37 & 31 & 12 & 0 & 14 & 35 & 49 & 0 & 16 & 29 & 53 & 8 & 20 & 24 & 47 \\
\hline 24 & 55 & 10 & 4 & 12 & 25 & 35 & 24 & 8 & 31 & 35 & 24 & 10 & 35 & 27 & 25 \\
\hline 25 & 47 & 16 & 6 & 0 & 22 & 49 & 27 & 4 & 10 & 53 & 29 & 4 & 16 & 51 & 27 \\
\hline 10 & 57 & 24 & 2 & 2 & 33 & 37 & 25 & 2 & 24 & 47 & 25 & 8 & 27 & 39 & 24 \\
\hline
\end{tabular}

\begin{tabular}{|l|l|l|l|l|}
\hline $\begin{array}{l}\text { 15. Overall work- } \\
\text { readiness }\end{array}$ & 8 & 31 & 42 & 15 \\
\hline
\end{tabular}

\begin{tabular}{|l|l|l|l|}
\hline 15 & 59 & 20 & 5 \\
\hline
\end{tabular}

\begin{tabular}{l|l|l|l|}
14 & 41 & 37 & 2 \\
\hline
\end{tabular}

Oliver, B., Whelan, B., Hunt, L., \& Hammer, S. (2011). Accounting graduates and the capabilities that count: Perceptions of graduates, employers and Accounting academics in four Australian

Universities.

Journal of Teaching and Learning for Graduate Employability, 2(1), 2 - 27. 
Table 5: Accounting graduate, employer and course team perceptions (percentage agreement: 'more' or 'less') of (1) the extent the fourteen capabilities are developed or demonstrated; (2) their importance to early professional success; and (3) course team confidence in teaching and assessing them. Colour coding highlights strengths, challenges, and opportunities for improvement.

\begin{tabular}{|l|c|c|c|c|}
\hline \multirow{2}{*}{ Capability } & \multicolumn{4}{|c|}{ Graduate perceptions ( $\mathrm{n}=316)$} \\
\cline { 2 - 5 } & \multicolumn{2}{|c|}{$\begin{array}{c}\text { Extent degree } \\
\text { contributed }\end{array}$} & \multicolumn{2}{|c|}{$\begin{array}{c}\text { Importance to } \\
\text { success }\end{array}$} \\
\hline & Less & More & Less & More \\
\hline $\begin{array}{l}\text { 1. Work related knowledge and } \\
\text { skills }\end{array}$ & 39 & 57 & 11 & 81 \\
\hline 2. Writing clearly and effectively & 30 & 65 & 15 & 79 \\
\hline 3. Speaking clearly and effectively & 40 & 56 & 12 & 79 \\
\hline 4. Thinking critically and analytically & 25 & 71 & 7 & 85 \\
\hline 5. Analysing quantitative problems & 22 & 73 & 13 & 79 \\
\hline $\begin{array}{l}\text { 6. Using computing and information } \\
\text { technology }\end{array}$ & 27 & 68 & 11 & 82 \\
\hline 7. Working effectively with others & 35 & 60 & 10 & 81 \\
\hline 8. Learning effectively on your own & 18 & 77 & 15 & 71 \\
\hline $\begin{array}{l}\text { 9. Understanding people of other } \\
\text { racial and ethnic backgrounds }\end{array}$ & 44 & 52 & 32 & 60 \\
\hline $\begin{array}{l}\text { 10. Solving complex, real-world } \\
\text { problems }\end{array}$ & 47 & 47 & 11 & 81 \\
\hline $\begin{array}{l}\text { 11. Developing a personal code of } \\
\text { values and ethics }\end{array}$ & 42 & 54 & 19 & 74 \\
\hline $\begin{array}{l}\text { 12. Contributing to the welfare of } \\
\text { your community }\end{array}$ & 59 & 36 & 41 & 52 \\
\hline $\begin{array}{l}\text { 13. Developing general industry } \\
\text { awareness }\end{array}$ & 39 & 54 & 20 & 70 \\
\hline $\begin{array}{l}\text { 14. Understanding different social } \\
\text { contexts }\end{array}$ & 51 & 43 & 35 & 56 \\
\hline
\end{tabular}

\begin{tabular}{|c|c|c|c|}
\multicolumn{4}{|c|}{$\begin{array}{c}\text { Employer perceptions } \\
(\mathrm{n}=99)\end{array}$} \\
\hline \multicolumn{2}{|c|}{$\begin{array}{c}\text { Extent } \\
\text { demonstrated }\end{array}$} & \multicolumn{2}{c|}{$\begin{array}{c}\text { Importance to } \\
\text { success }\end{array}$} \\
\hline Less & More & Less & More \\
\hline 70 & 29 & 26 & 70 \\
\hline 73 & 27 & 9 & 87 \\
\hline 57 & 42 & 2 & 94 \\
\hline 66 & 33 & 8 & 87 \\
\hline 65 & 35 & 12 & 85 \\
\hline 9 & 90 & 8 & 88 \\
\hline 49 & 49 & 5 & 91 \\
\hline 57 & 42 & 14 & 81 \\
\hline 57 & 42 & 33 & 63 \\
\hline 88 & 12 & 27 & 69 \\
\hline 57 & 42 & 9 & 87 \\
\hline 82 & 17 & 46 & 49 \\
\hline 80 & 20 & 30 & 66 \\
\hline 77 & 22 & 36 & 60 \\
\hline
\end{tabular}

\begin{tabular}{|c|c|c|c|}
\hline \multicolumn{2}{|c|}{$\begin{array}{c}\text { Extent } \\
\text { demonstrated }\end{array}$} & \multicolumn{2}{|c|}{$\begin{array}{c}\text { Course tear } \\
\begin{array}{c}\text { Importance to } \\
\text { success }\end{array}\end{array}$} \\
\hline Less & More & Less & More \\
\hline 69 & 26 & 10 & 88 \\
\hline 65 & 29 & 2 & 96 \\
\hline 45 & 47 & 0 & 97 \\
\hline 65 & 30 & 2 & 94 \\
\hline 39 & 55 & 6 & 92 \\
\hline 14 & 80 & 6 & 92 \\
\hline 51 & 43 & 4 & 94 \\
\hline 45 & 49 & 10 & 88 \\
\hline 47 & 47 & 20 & 78 \\
\hline 68 & 26 & 14 & 84 \\
\hline 49 & 43 & 14 & 84 \\
\hline 79 & 14 & 37 & 59 \\
\hline 72 & 22 & 22 & 76 \\
\hline 67 & 26 & 35 & 62 \\
\hline
\end{tabular}

\section{ptions $(n=51)$}

Strengths: \% agreement that capability is MORE ('quite a bit or very much') important or demonstrated Challenges: \% agreement that capability is LESS ('quite a bit or very much') important or demonstrated.

\begin{tabular}{|c|c|c|c|}
\hline \multicolumn{2}{|c|}{$\begin{array}{c}\text { Confidence } \\
\text { teaching }\end{array}$} & \multicolumn{2}{c|}{$\begin{array}{c}\text { anfidence } \\
\text { assessing }\end{array}$} \\
\hline Less & More & Less & More \\
\hline 12 & 86 & 14 & 86 \\
\hline 18 & 80 & 14 & 84 \\
\hline 16 & 82 & 14 & 84 \\
\hline 6 & 92 & 10 & 88 \\
\hline 6 & 92 & 10 & 88 \\
\hline 18 & 80 & 16 & 82 \\
\hline 14 & 84 & 28 & 70 \\
\hline 14 & 84 & 26 & 70 \\
\hline 22 & 74 & 30 & 68 \\
\hline 14 & 84 & 18 & 80 \\
\hline 16 & 82 & 28 & 71 \\
\hline 39 & 59 & 45 & 52 \\
\hline 14 & 82 & 20 & 78 \\
\hline 26 & 72 & 35 & 63 \\
\hline
\end{tabular}

Oliver, B., Whelan, B., Hunt, L., \& Hammer, S. (2011). Accounting graduates and the capabilities that count: Perceptions of graduates, employers and Accounting academics in four Australian Universities. 


\section{Perceptions of the capabilities by each stakeholder group}

Figure 1 shows a comparison of graduate perceptions of extent and importance: that is, the extent to which the degree experience contributed to capability development (percentage agreement 'quite a bit' or 'very much') versus the importance of each (percentage agreement 'quite a bit' or 'very important'). Ideally, the two data lines would be in close proximity, indicating that what is perceived as important is developed to a similar extent. This is the case for Learning effectively on your own, and to a lesser extent Analysing quantitative problems and Understanding people of other racial and ethnic backgrounds. The greatest discrepancies, where extent is at least twenty percentage points less than importance, are Solving complex, real-world problems, Work-related knowledge and skills, Speaking clearly and effectively, Working effectively with others and Developing a personal code of values and ethics.

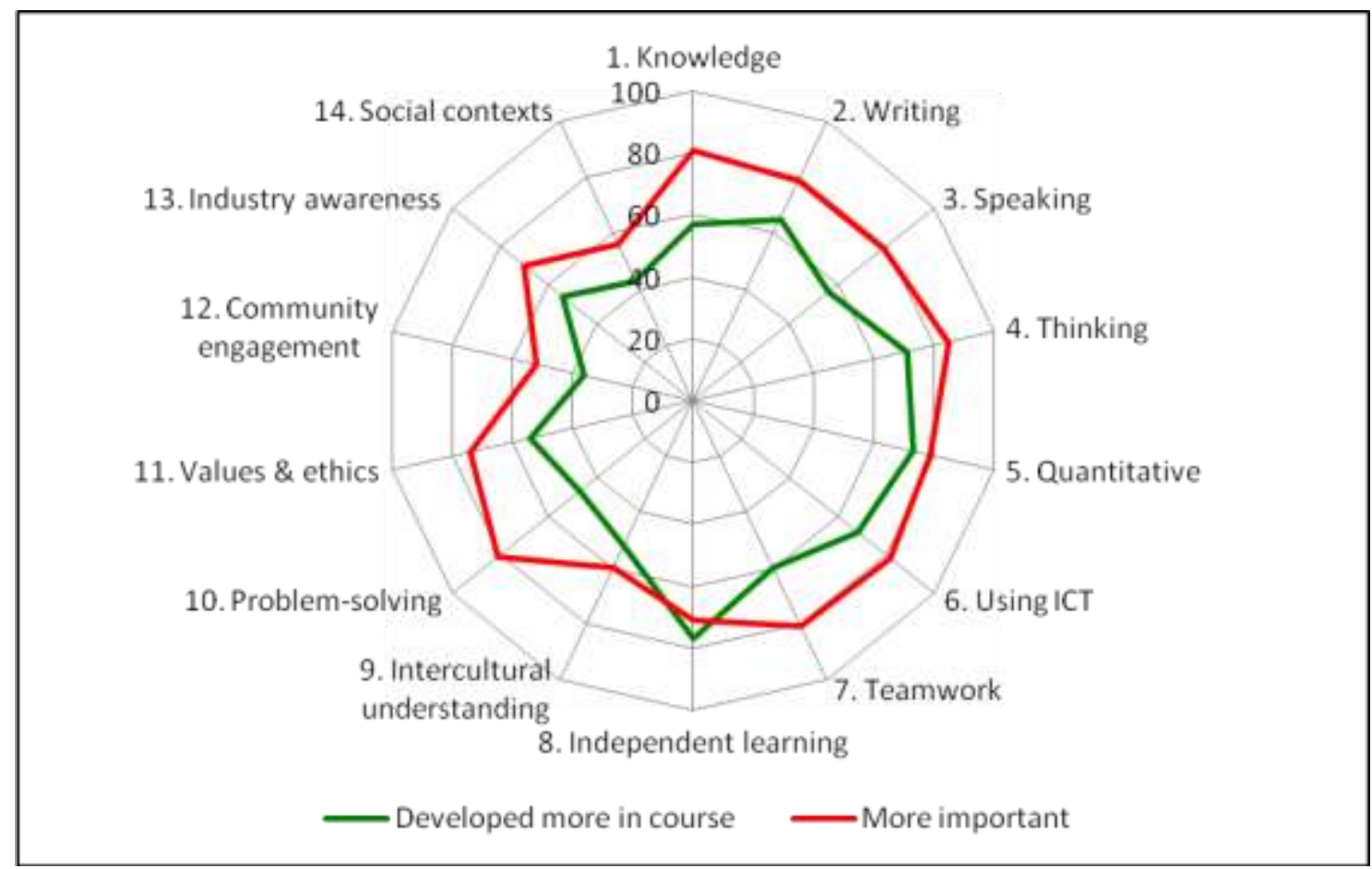

Figure 1: Comparison of graduate perceptions of the capabilities developed more (percentage agreement with 'quite a bit' or 'very much') versus capabilities that are more important (percentage agreement 'quite' or 'very important')

The same parameters are used in the following figures showing employers and course team perceptions. Figure 2, employer perceptions, shows more dramatic discrepancies in all capabilities with the exception of ICT, where importance and extent demonstrated are similar. Otherwise, demonstration is less than importance by at least 50 percentage points in relation to Writing and speaking clearly and effectively, Thinking critically and analytically, Analysing quantitative problems and Solving complex, real-world problems. 


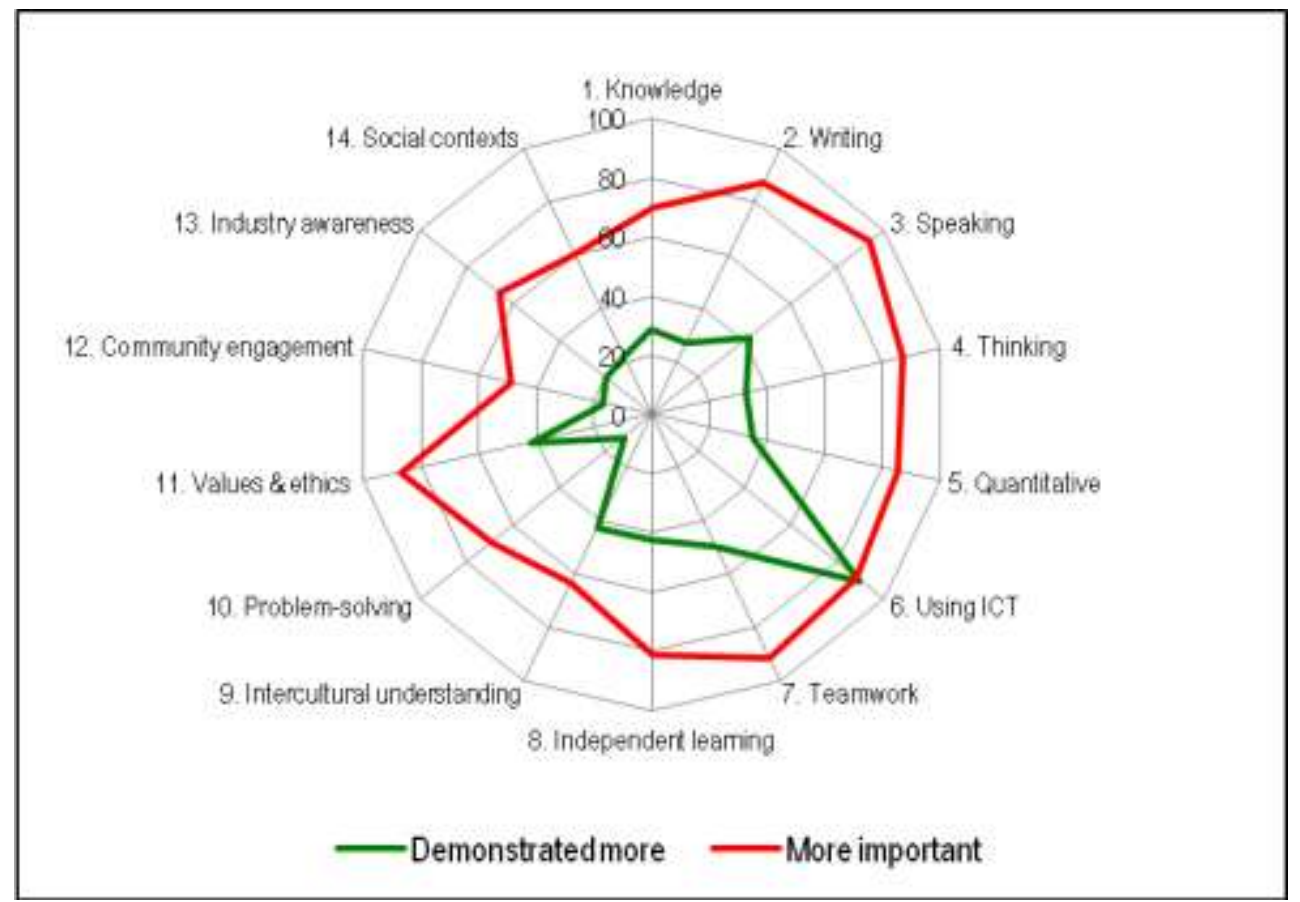

Figure 2: Comparison of employer perceptions of the capabilities demonstrated more (percentage agreement with 'quite a bit' or 'very much') versus capabilities that are more important (percentage agreement 'quite' or 'very important')

Figure 3 shows course team perceptions. Once again, discrepancies greater than 50 percentage points, indicating that demonstration is less than importance, are in

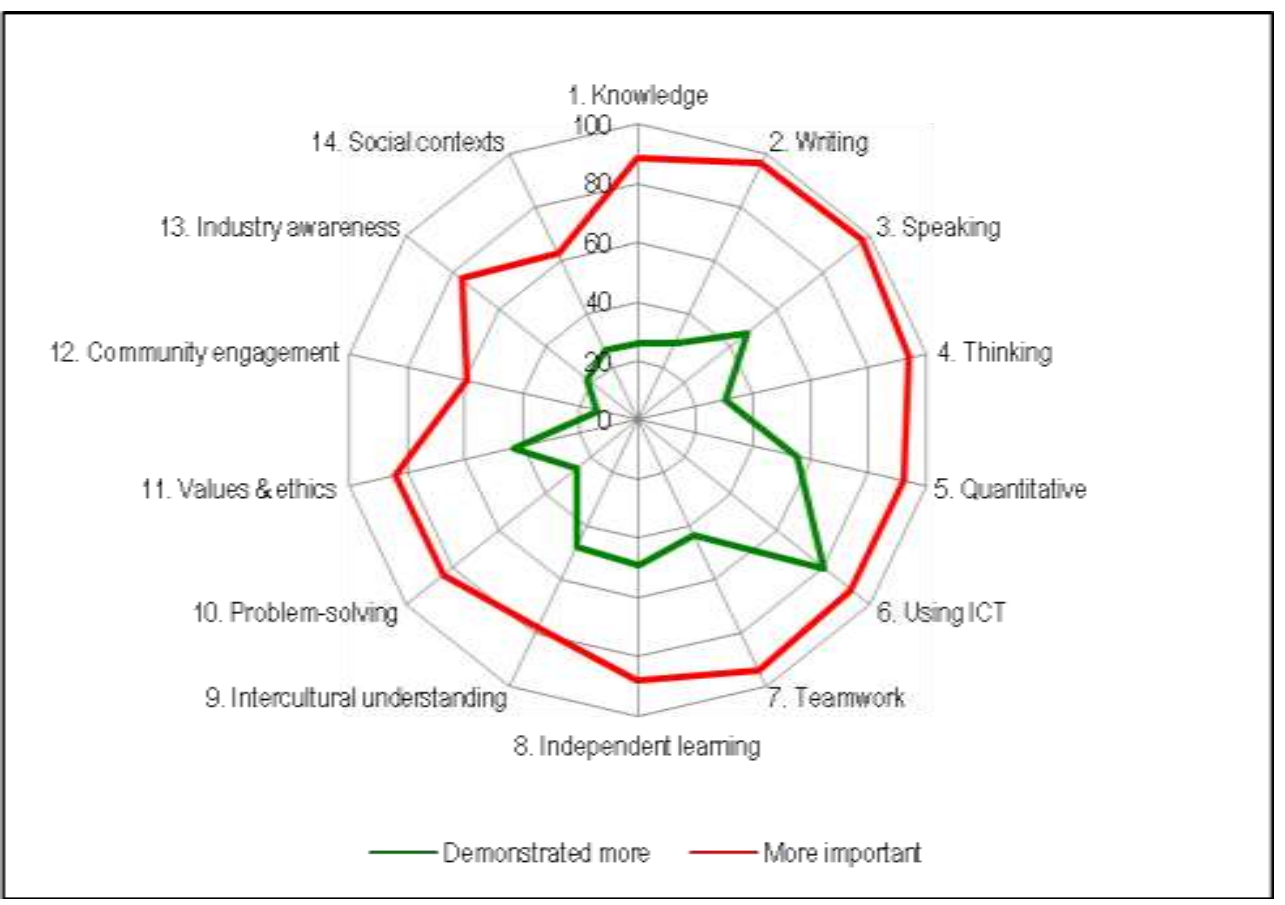

Figure 3: Comparison of course team perceptions of the capabilities demonstrated more (percentage agreement with 'quite a bit' or 'very much') versus capabilities that are more important (percentage agreement 'quite' or 'very important')

Oliver, B., Whelan, B., Hunt, L., \& Hammer, S. (2011). Accounting graduates and the capabilities that count: Perceptions of graduates, employers and Accounting academics in four Australian Universities. Journal of Teaching and Learning for Graduate Employability, 2 (1), 2 - 27. 
relation to Work related knowledge and skills, Writing clearly and effectively, Speaking clearly and effectively, Thinking critically and analytically, Analysing quantitative problems, Working effectively with others and Developing general industry awareness.

\section{Triangulation of stakeholder perceptions}

Figure 4 presents a triangulation of the stakeholder groups' perceptions of the capabilities that are more important for professional success. The figure shows that the three stakeholder groups have similar emphasis in most capabilities. Discrepancies of about twenty percentage points may be seen in relation to Workrelated knowledge and skills (less important to employers), Writing and speaking clearly and effectively (less important to graduates), and Understanding people of other racial and ethnic backgrounds (more important to course teams).

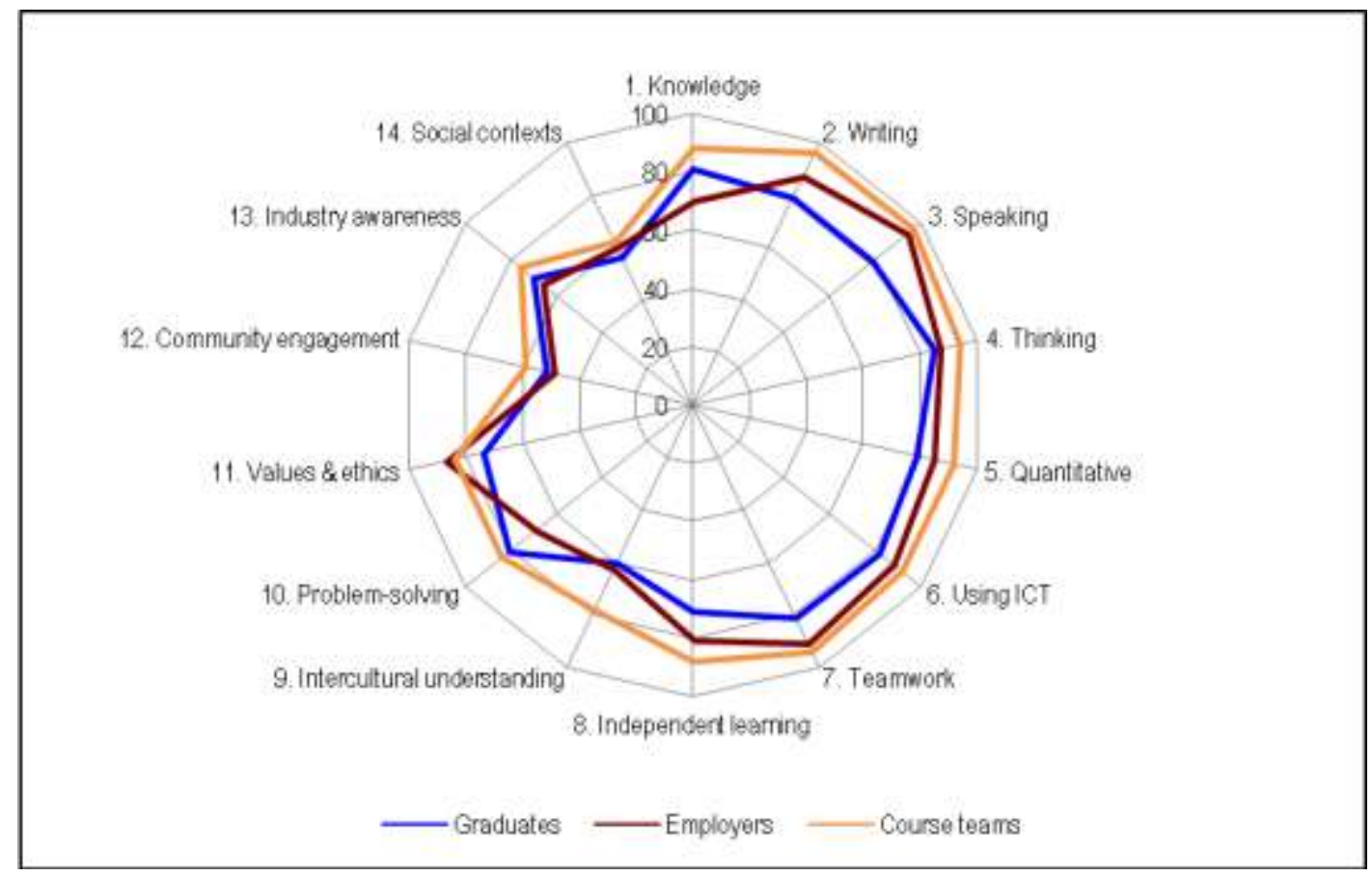

Figure 4: A comparison of graduate, employer and course team perceptions of capabilities perceived as more important to early professional success (percentage agreement 'quite' or 'very important')

Similarly, Figure 5 shows a comparison of perceptions of the capabilities demonstrated more by graduates (according to employers and course teams) or developed more in courses (according to graduates). The figure shows close similarity between employer and course team perceptions: apart from Using computing and information technology, few capabilities are demonstrated to a high degree (according to employers and course teams). The capability most developed in degree programs, according to graduates, is Learning effectively on your own. 


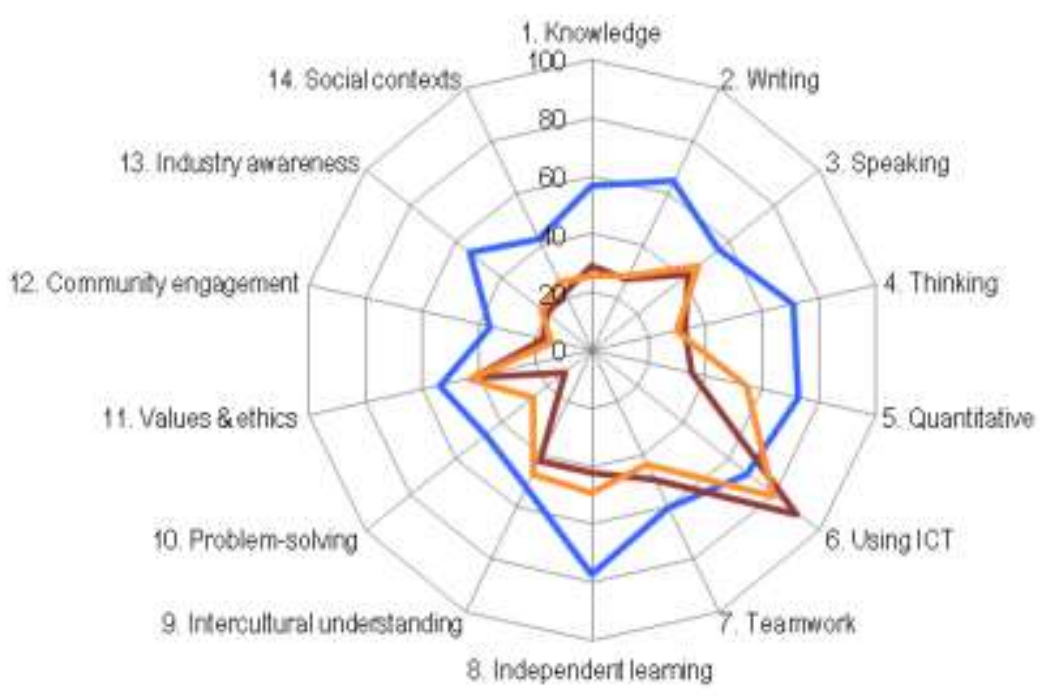

-Graduates Employers - Courseteams

Figure 5: Comparison of graduate, employer and course team perceptions of capabilities perceived as demonstrated or developed more ('quite a bit' or 'very much')

\section{Qualitative responses}

Graduates were invited to provide free text responses to two items: 'What were the best aspects of this degree in developing your skills for employment?' and 'How could the degree be changed to improve your skills for employment?' For convenience, these are referred to as Best Aspects and Needs Improvement. In total, 209 respondents provided a response to one or both questions (198 respondents on the Best Aspects and 196 on Needs improvement). These comments were plotted as visualisations using SPSS Text Analysis for Surveys, as shown in Figures 6 and 7 below. In these visualisations, a line shows that there is a connection between two themes, with darker, thicker lines representing stronger relationships, and larger nodes indicating more responses.

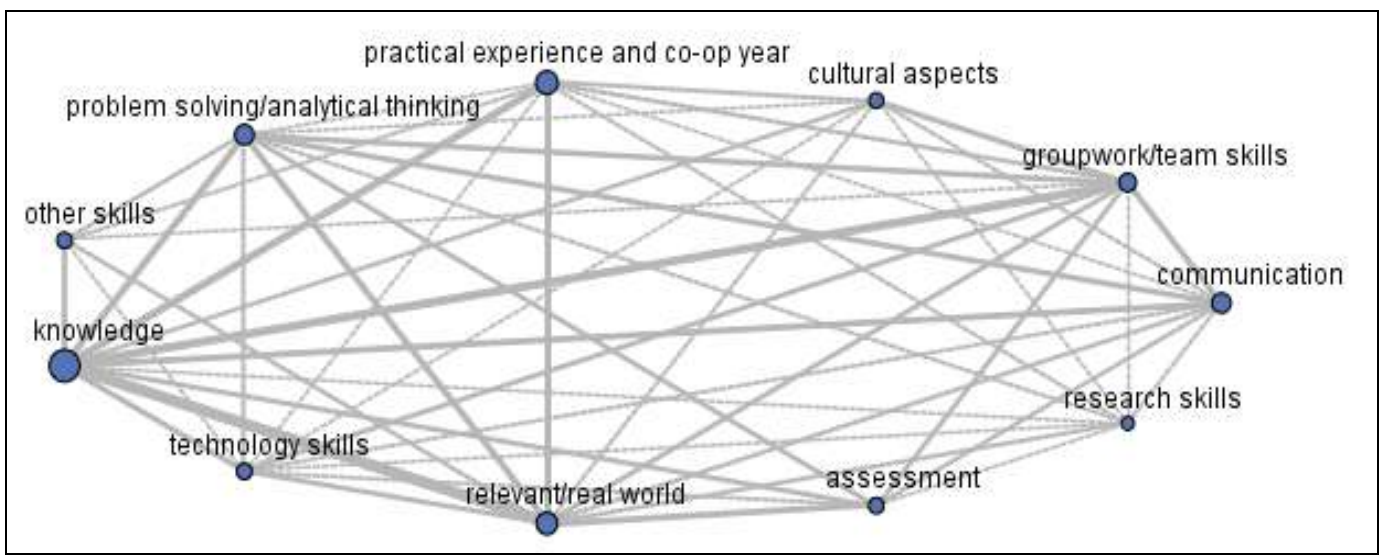

Figure 6: An SPSS visualisation of graduate comments in response to 'What were the best aspects of this degree in developing your skills for employment?' 
Figure 6 suggests that graduates were more positive about discipline knowledge and skills in communication, problem-solving, analytical thinking, technology, research and teamwork. Graduates also made reference to the practical real-world experiences and cultural dimensions. Figure 7 suggests that when asked 'How could the degree be changed to improve your skills for employment?' graduates focused on work and 'real world' experiences and assignments. Specific skills mentioned more frequently were teamwork, problem-solving, thinking, research and communication skills.

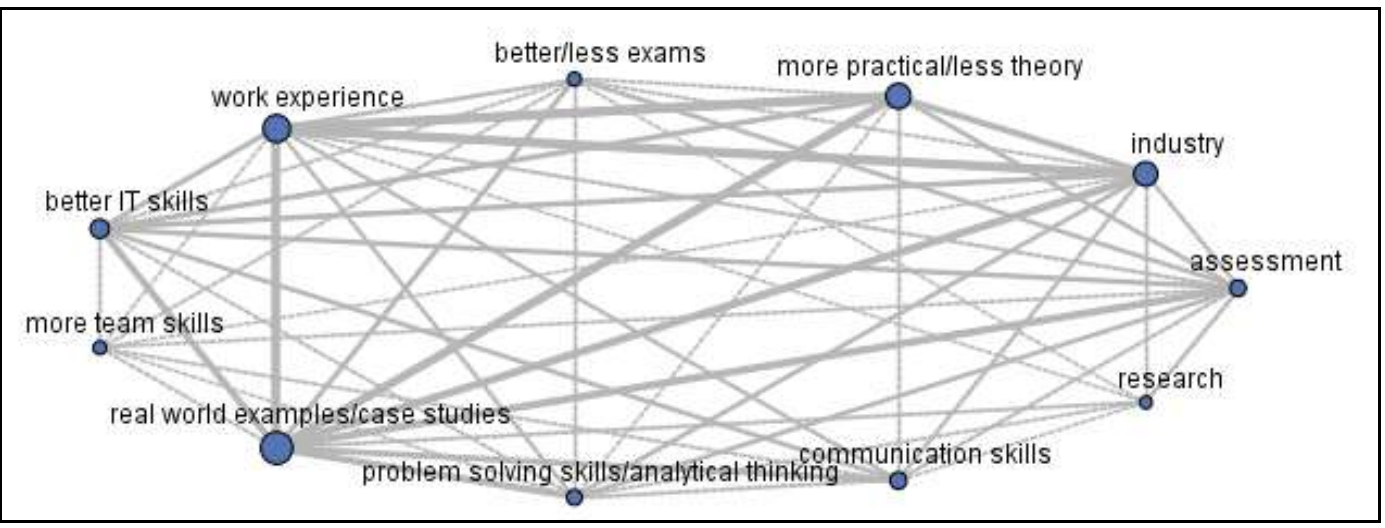

Figure 7: An SPSS visualisation of graduate comments in response to 'How could the degree be changed to improve your skills for employment?

Similarly, employers were invited to provide free text responses on the skills, attributes and personal qualities most useful for new graduates and which (if any) could be prioritised for improvement? In all, 85 employers provided comments on the most useful capabilities, and 68 provided comments on the capabilities in need of improvement. Figures 8 and 9 show the emphases in the responses.

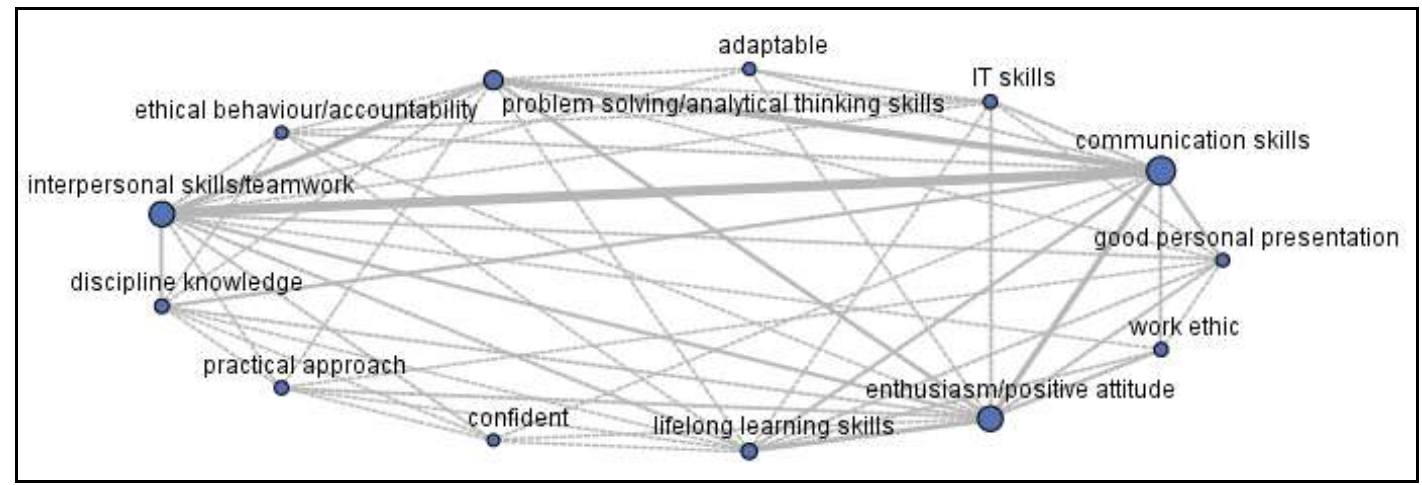

Figure 8: An SPSS visualisation of employer comments in response to 'What skills, attributes and personal qualities do you consider to be the most useful for new graduates in this field?'

Figure 8 suggests that employers perceived the most useful skills, attributes and personal qualities as communication and interpersonal skills, enthusiasm and positive attitude. They also made particular reference to good personal presentation, confidence, work ethic, adaptability, ethical behaviour and accountability. Figure 9 suggests that, in terms of areas for improvement, employers clearly emphasise communication skills, as well as interpersonal skills, personal grooming, integrity and 
honesty, respect, motivation, adaptability and confidence. They also mentioned the need for humility, respect, and the ability to take direction.

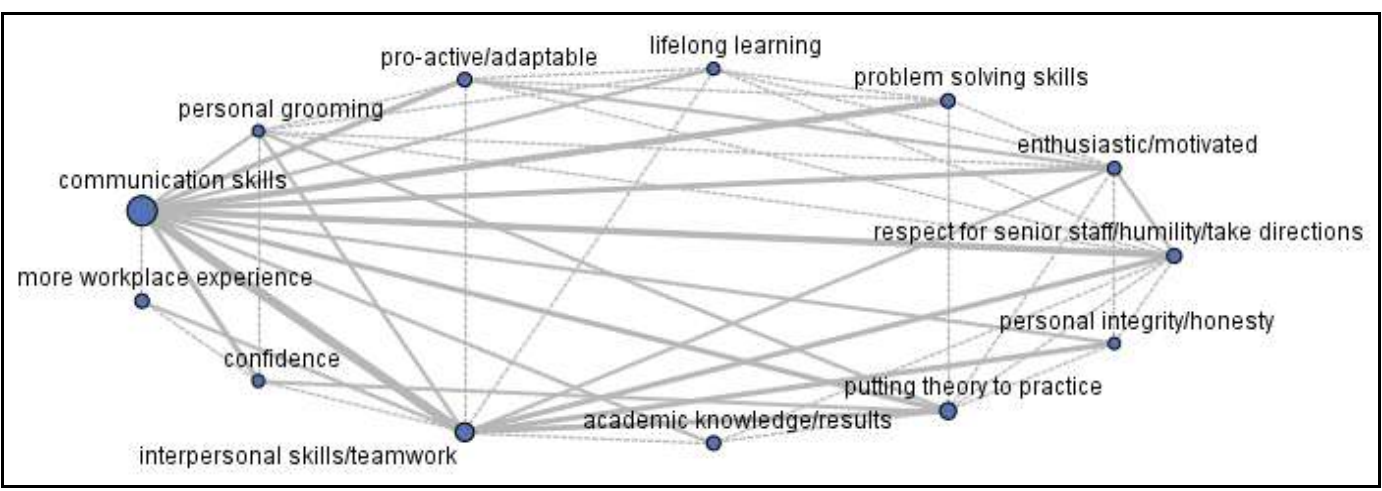

Figure 9: An SPSS visualisation of employer comments in response to 'Which (if any) skills, attributes and personal qualities of new graduate attributes would you prioritise for improvement?'

Course teams from the four partner universities were invited to provide free text comments in response to four questions, and themes in their responses are summarised here. When asked 'What do you see as the main incentives for teaching staff to assist students to develop work-related skills, attributes and personal qualities?' members of the course teaching teams identified benefits to their institution, course, industry and the students/graduates as the main incentives. Many made reference to personal satisfaction and the benefits that can be derived from better links with industry. Some stated that 'there are no incentives', which might relate to the perceived beneficiaries of graduate employability skill development being institutions, industry and graduates, rather than their teachers. Similar findings can be drawn from the responses to the second open-ended question which asked: 'What do you see as the main disincentives for teaching staff to assist students to develop work-related skills, attributes and personal qualities?' The main disincentives included workload and resourcing issues, such as a lack of time, support or space in the curriculum to teach graduate employability skills, attributes and personal qualities. Some respondents made reference to their own lack of skills and training in teaching such capabilities, as well as issues with assessing such capabilities. Large classes with students lacking interest were also seen as disincentives, as was the lack of recognition or reward for teaching staff who do undertake employability skill development. This suggests that for members of the course teaching team to embrace employability skill development, they must be given the time, resources and rewards (such as recognition).

When asked what they saw as their role in assisting students to develop these attributes, skills and personal qualities, respondents saw themselves as facilitators, mentors, or role models in developing students' employability skills, with the role of encouraging and motivating students and building their confidence. Some teaching staff made reference to particular capabilities that they helped to develop, such as problem solving, team work, ethics and technology skills. They also saw it as their role to share their own professional experience. In relation to the staff development opportunities that would increase their confidence to teach and assess work-related skills, attributes and personal qualities, respondents frequently nominated 
experiences related directly to industry, such as greater links to industry through staff industry placements, consultancies or research connections, and developing industry focussed teaching. Collaboration with other academics and embarking on further education were also mentioned as opportunities that would increase course team confidence. Holding workshops or seminars on particular teaching and assessment issues, such as international and intercultural skills, technology skills or assessment methods were also mentioned.

\section{Prioritising areas for improvement using an importance-performance analysis}

The perception that the capabilities that count most are effected only a small extent in today's Accounting graduates may appear overwhelming. Teaching staff who have the power to enhance the curriculum and the student experience, but who are constrained by large teaching and administration loads and scarce resources, may feel at a loss as to where to begin. A useful tool developed by Martilla and James is an importance-performance analysis, a method used to determine the effectiveness and consumer acceptance of marketing programs (Martilla \& James, 1977). Essentially, items are plotted on an $X$ and $Y$ axis (in a scattergram) with Performance on the $X$ axis, and Importance plotted on the $Y$ axis. The Martilla and James model was adapted for use in an educational context as part of the research on competences in the Tuning process (Villa et al., 2008). The four quadrants generated in the Tuning grid indicate where to apply more concentration, maintain or decrease effort. The Tuning example has been adapted for use here: Figure 10 shows a grid with four quadrants. The GEI results are plotted as follows: each capability is plotted on the grid $(X, Y)$ as follows: $X=$ percentage agreement ('quite a bit' or 'very much') extent demonstrated or developed; $Y=$ percentage agreement ('quite a bit' or 'very much') importance. Each stakeholder group is colour coded. The model is further adapted by the inclusion of a green zone in the top left quadrant: any capabilities plotted in the green zone are those identified as most important yet demonstrated or developed least. Identifying these capabilities-and taking into consideration which stakeholders rated them-is a useful tool to highlight urgent need for improvement. The importance-performance analysis for Accounting in Figure 10 suggests that priority attention could be given to capabilities 1, 2, 4, 10 and 13: that is, Work related knowledge and skills, Writing clearly and effectively, Thinking critically and analytically, Solving complex, real-world problems and Developing general industry awareness.

Oliver, B., Whelan, B., Hunt, L., \& Hammer, S. (2011). Accounting graduates and the capabilities that count: 


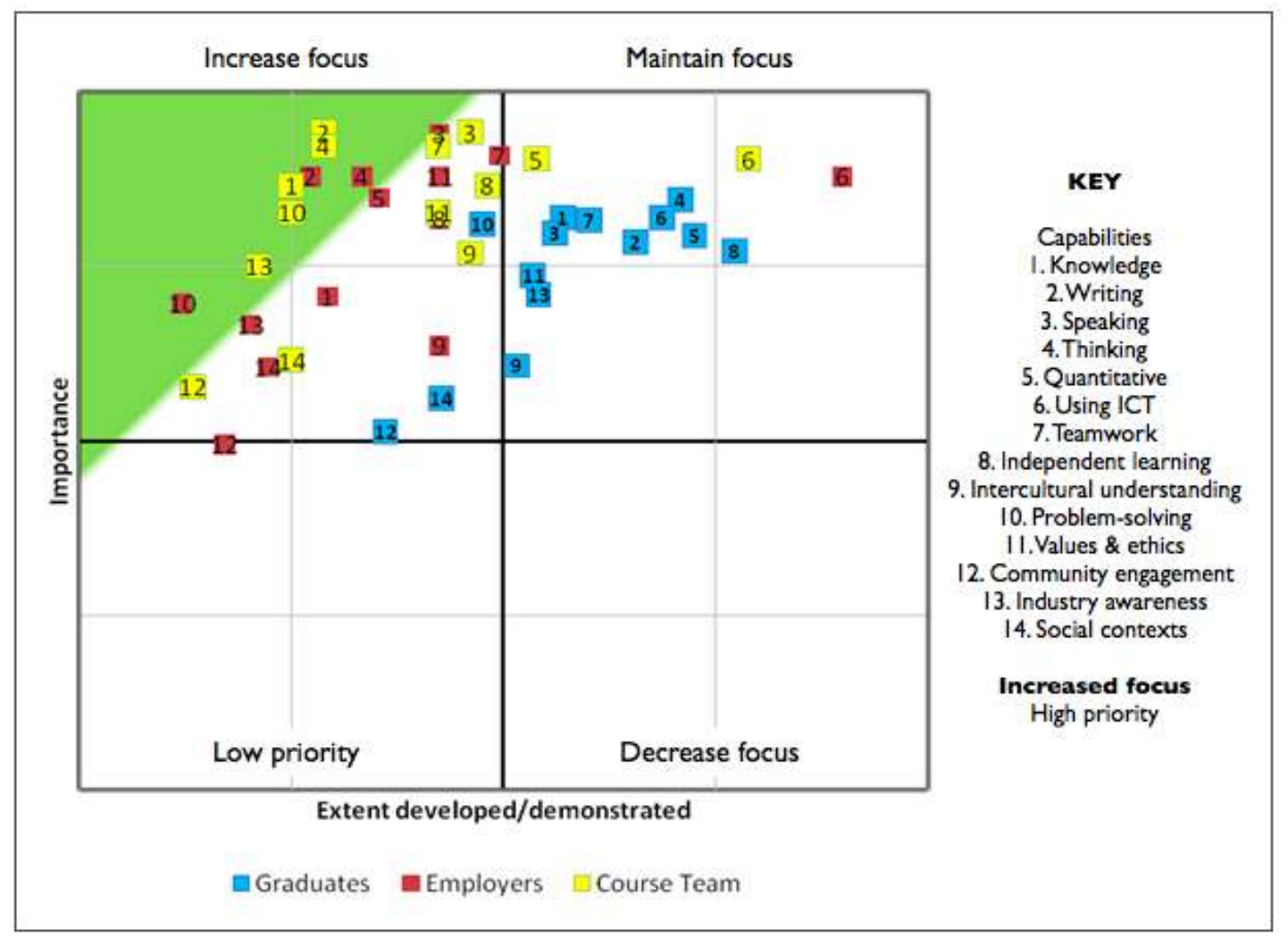

Figure 10: Importance-performance analysis showing capabilities for urgent attention based on each stakeholder group's perceptions of importance and extent (percentage agreement 'quite a bit' or very much')

\section{Discussion}

In spite of the challenges associated with attracting respondents, 316 graduates, 99 employers and 51 members of undergraduate Accounting course teams from four Australian universities provided GEI responses. Whether each stakeholder group is representative of the wider population is unknown because comprehensive data for the four partners are unavailable. Further research using larger samples or sampling (purposeful or random) will be necessary to determine the extent to which the views expressed by each stakeholder group in this study are representative and to determine the sensitivity of the GEI. In particular, the GEI should be extended to more university and private providers and a larger sample of male graduates, graduates of more than 3 years and female employer groups.

Findings of this study showed that the respondents appeared to have similar perceptions about the fourteen capabilities in the GEI: most were considered 'more important' to early professional success by most stakeholder groups. The capabilities rated more important by most groups were Work-related knowledge and skills, Writing and speaking clearly and effectively, Working effectively with others, Learning effectively on your own, Using computing and information technology and Developing a personal code of values and ethics. In their free text responses, when asked about the best aspects of their course in developing skills for employment, graduates frequently mentioned similar capabilities: discipline knowledge, communication, 
problem-solving, analytical thinking, technology, research and teamwork. They also made reference to the practical real-world experiences and cultural dimensions. Employers perceived the most useful skills, attributes and personal qualities as communication and interpersonal skills, enthusiasm and positive attitude. This is not dissimilar to the findings of Hancock et al who found that when employers had to choose between applicants of similar academic ability, they chose the applicant who displayed strength in these generic capabilities (Hancock et al., 2010).

A main benefit from the GEl is that it asks 'what are the capabilities that count (importance), and to what extent are they generally demonstrated by graduates (according to employers and teaching staff), or developed in courses (according to graduates)'? Again, similar results from the Hancock et al. study indicated that concerns about Australian graduates' generic capabilities were focused on analytical and critical analysis, and the ability to engage clients, negotiate and act strategically (Hancock et al., 2010).

Examining perceptions of importance, demonstration and delivery of skills revealed that the greatest discrepancies for graduates were in relation to Solving complex, real-world problems, Work-related knowledge and skills, Speaking clearly and effectively, Working effectively with others and Developing a personal code of values and ethics. These capabilities were not seen by graduates to be developed to a level that accorded with their views about the importance of these skills. The mismatch of employer and course team perceptions were more dramatic (and similar to each other): apart from ICT expertise, most other capabilities were seen as important but not demonstrated to an appropriate level, particularly Writing and speaking clearly and effectively, Thinking critically and analytically, Analysing quantitative problems and Solving complex, real-world problems. The importance-performance analysis provides direction for curriculum development in Accounting indicating that, in the face of scarce resources and staff pressures (workload, time and space in the curriculum), priority attention should be given to capabilities such as Work related knowledge and skills, Writing clearly and effectively, Thinking critically and analytically, Solving complex, real-world problems and Developing general industry awareness. Evidence from course team qualitative comments indicates that they are often intrinsically motivated and many would welcome opportunities to have more industry experience - two thirds of respondents had not had recent experience. Staff would also welcome workshops designed specifically to assist them to embed such experience into the curriculum.

Course team members showed high confidence in teaching and assessing most of the fourteen capabilities-sadly, their efforts are not perceived as particularly effective by employers or by themselves. The reason may be linked to other recent Australian studies showing that graduate attributes have not been universally endorsed or embedded in Australian curricula (Barrie et al., 2009; Precision Consulting, 2007; Radloff, A., de La Harpe, B., Scoufis, M., Dalton, H., Thomas, J., Lawson, A., et al, 2009), partly because, teaching staff say, that excessive content leaves little time for skill development, and partly because staff lack the expertise to embed such skills in the curriculum (Evans, 2010). In relation to the staff development opportunities course team members frequently suggested staff industry placements, consultancies or research connections, and developing industry focussed teaching. They also welcome targeted seminars and workshops. 
Graduates perceptions of the capabilities developed in their courses may be influenced by the visibility of skills in the curriculum. It might therefore be a useful curriculum strategy to ensure that students (and graduates) are reminded, during and beyond the degree program, of the specific capabilities under development (including in work integrated learning experiences such as placements authentic assessments) - through study guides, assessment rubrics and criteria, eportfolios, and other teaching and learning strategies.

The findings of this study suggest that much work is needed to improve awareness of graduate employability skills among all stakeholder groups: $57 \%$ of graduates indicated that they felt their degree had contributed to their work-readiness 'quite a bit' or 'very much'. Only $25 \%$ of employers shared this view, as did $39 \%$ of course team members. Graduates would welcome more industry experience during their courses, but work placements for large cohorts are unrealistic-in many contexts, students would outnumber placement opportunities. The literature suggests that, attractive as they may appear, work placements are not the key to enhanced employability - reflection on what has been learned during the placement is what makes the difference (Harvey, 2005). In the case of Accounting, work integrated learning experiences for most students are more likely to be simulated than live: if staff can have increased access to industry experience, and build their experiences into authentic assessment tasks, this may go some way towards increased graduate awareness that their degree program contributed to their development of the capabilities that count. Authentic tasks have been characterised as ill-defined tasks of real world relevance, open to multiple interpretations, investigated over a sustained period of time, examinable from a variety of theoretical and practical perspectives, drawing on a variety of resources, and providing the opportunity to collaborate and reflect (Herrington, Oliver, \& Reeves, 2003). If assessment drives learning, and assessment tasks were remodelled around such authentic tasks, then there is greater likelihood that Accounting graduates will achieve, and be seen to achieve "the skills, understandings and personal attributes that make [them] more likely to secure employment and be successful in their chosen occupations to the benefit of themselves, the workforce, the community and the economy" (Yorke, 2006 p.8).

Oliver, B., Whelan, B., Hunt, L., \& Hammer, S. (2011). Accounting graduates and the capabilities that count: Perceptions of graduates, employers and Accounting academics in four Australian Universities. Journal of Teaching and Learning for Graduate Employability, 2 (1), 2 - 27. 


\section{References}

Ainley, J., \& Johnson, T. (2000). Course Experience Questionnaire 2000: An interim report prepared for the Graduate Careers Council of Australia: Australian Council for Educational Research.

Association of American Colleges and Universities. (2004). Liberal Education and America's Promise (LEAP): Essential Learning Outcomes. Retrieved 4 September 2010 from http://www.aacu.org/leap/.

Association of American Colleges and Universities. (2005). Liberal Education Outcomes: A Preliminary Report on Student Achievement in College. Washington DC: Association of American Colleges and Universities. Retrieved 4 September 2010 from http://www.aacu.org/leap/pdfs/LEAP Report FINAL.pdf.

Association of American Colleges and Universities. (2007). College learning for the new global century: A report from the National Leadership Council for Liberal Education and America's Promise. Retrieved 20 July, 2010 from http://www.aacu.org/leap/documents/GlobalCentury final.pdf.

Australian Council for Educational Research. (2005). Graduate Skills Assessment. Retrieved 28 November 2010 from http://www.acer.edu.au/tests/university/gsa/intro.html.

Barrie, S., Hughes, C., \& Smith, C. (2009). The National Graduate Attributes Project: Integration and assessment of graduate attributes in curriculum. Sydney: Australian Learning and Teaching Council

Coates, H. (2009). Engaging Students for Success: Australasian Student Engagement Report. Melbourne: Australian Council for Educational Research.

Coates, H., \& Edwards, D. (2009). The 2008 Graduate Pathways Survey: Graduates' education and employment outcomes five year after completion of a bachelor degree at an Australian university. Melbourne: Australian Council for Educational Research. Retrieved 12 December 2010 from http://forms.acer.edu.au/documents/GPS FullReport.pdf.

Department of Education Employment and Workplace Relations. (2010). Mission based compacts explanatory paper. Canberra: DEEWR. Retrieved 22 January 2010 from http://www.deewr.gov.au/HigherEducation/Policy/Documents/FinalCompactT emplate.pdf.

Evans, E. (2010). Jurisdictional Disputes in Accounting: Education or Training? In E. Evans, R. Burritt \& J. Guthrie (Eds.), Accounting Education at a Crossroad in 2010 (pp. 80-89). Sydney: The Institute of Chartered Accountants in Australia.

Freeman, M. (2010). Setting Discipline Standards for Accounting Education, Learning and Teaching. In E. Evans, R. Burritt \& J. Guthrie (Eds.), Accounting Education at a Crossroad in 2010 (pp. 41-53). Sydney: The Institute of Chartered Accountants in Australia.

Gonzalez, J., \& Wagenaar, R. (2008). Universities' contribution to the Bologna Process. Spain: Tuning Project 
Hancock, P., Howieson, B., Kavanagh, M., Kent, J., Tempone, I., \& Segal, N. (2010). Accounting for the Future. In E. Evans, R. Burritt \& J. Guthrie (Eds.), Accounting Education at a Crossroad in 2010 (pp. 54-62). Sydney: The Institute of Chartered Accountants in Australia.

Harvey, L. (2005). Embedding and integrating employability. New Directions for Institutional Research, 2005(128), 13-28. Retrieved 10 December 2010 from http://dx.doi.org/10.1002/ir.160.

Herrington, J., Oliver, R., \& Reeves, T. C. (2003). Patterns of engagement in authentic online learning environments. Australian Journal of Educational Technology, 19(1), 59-71. Retrieved 12 December 2010 from http://www.ascilite.org.au/ajet/ajet19/herrington.html.

Knight, P., \& Yorke, M. (2004). Learning, Curriculum and Employability in Higher Education. London: Routledge Farmer.

Kuh, G. D. (2001). The National Survey of Student Engagement: Conceptual framework and overview of psychometric properties. Bloomington, Indiana: Indiana University Center for Postsecondary Research.

Lightbody, M. (2010). The Impact of Accreditation on Accounting Education in 2010. In E. Evans, R. Burritt \& J. Guthrie (Eds.), Accounting Education at a Crossroad in 2010 (pp. 29-34). Sydney: The Institute of Chartered Accountants in Australia.

Martilla, J. A., \& James, J. C. (1977). Importance-Performance Analysis. The Journal of Marketing, 41(1), 77-79.

Mclnnis, C., Griffin, P., James, R., \& Coates, H. (2001). Development of the Course Experience Questionnaire (CEQ): Evaluations and Investigations Programme, Higher Education Division, Department of Education, Training and Youth Affairs.

Milburn, C. (2010, 15 March). Uni survey finds job focus is missing. The Age. Retrieved 22 November 2010 from http://www.theage.com.au/national/education/uni-survey-finds-job-focus-ismissing-20100314-q5x9.html.

Miller, R., \& Leskes, A. (2005). Levels of Assessment: From the Student to the Institution. Washington DC: Association of American Colleges and Universities.

Nicoll, C. (2010, 1 September). Fields determine how standards shift. The Australian. Retrieved 22 November 2010 from http://www.theaustralian.com.au/highereducation/opinion-analysis/fields-determine-how-standards-shift/storye6frgcko-1225912502783.

Parker, L. D. (2010). Introducing the Commercialised University Environment: Preliminary Reflections on the Trajectory of Change. In E. Evans, R. Burritt \& J. Guthrie (Eds.), Accounting Education at a Crossroad in 2010 (pp. 16-21). Sydney: The Institute of Chartered Accountants in Australia.

Precision Consulting. (2007). Graduate employability skills. Melbourne: Business, Industry and Higher Education Collaboration Council. Retrieved 12 January 2010 from http://www.dest.gov.au/NR/rdonlyres/E58EFDBE-BA83-430E-A5412E91BCB59DF1/20214/GraduateEmployabilitySkillsFINALREPORT1.pdf. 
Quality Assurance Agency. (n.d.). Subject benchmark statements. Retrieved 10 May, 2010 from

http://www.qaa.ac.uk/academicinfrastructure/benchmark/default.asp.

Radloff, A., de la Harpe, B., Scoufis, M., Dalton, H., Thomas, J., Lawson, A., et al. (2009). The B Factor Project: Understanding academic staff beliefs about graduate attributes. Melbourne: Australian Learning and Teaching Council.

Ramsden, P. (1999). The CEQ looking back and forward. In Course Experience Questionnaire Symposium 1998 Proceedings, T.Hand \& K.Trembath (Eds.), Department of Training and Youth Affairs. Sydney : The University of New South Wales)

Richardson, J. T. E. (2005). Instruments for obtaining student feedback: A review of the literature. Assessment and Evaluation in Higher Education, 30(4), 387415.

Ryan, S. (2010). Business and Accounting Education: Do They Have a Future in the University? In E. Evans, R. Burritt \& J. Guthrie (Eds.), Accounting Education at a Crossroad in 2010 (pp. 22-28). Sydney: The Institute of Chartered Accountants in Australia.

Scott, G. (2005). Accessing the student voice: Using CEQuery to identify what retains students and promotes engagement in productive learning in Australian higher education: HEIP. Retrieved 22 November 2010 from http://www.dest.gov.au/sectors/higher education/publications resources/profi les/access student voice.htm.

Stephenson, J. (1998). The concept of capability and its importance in higher education. In J. Stephenson \& M. Yorke (Eds.), Capability and quality in higher education (pp. 1-13). London: Kogan Page.

Villa, A., González, J., Auzmendi, E., Beza-nilla, M. J., \& Laka, J. P. (2008). Competences in the teaching and learning process. In J. González \& R. Wagenaar (Eds.), Universities' contribution to the Bologna Process (2nd ed., pp. 25-54). Spain: Tuning Project.

Whelan, B., Oliver, B., Hunt, L., Hammer, S., Jones, S., \& Pearce, A. (2010). Capturing stakeholder perceptions of graduate capability development: Challenges associated with Graduate Employability Indicators. Paper presented at the Australian Collaborative Education Network (ACEN) Conference, Perth. Retrieved 29 January 2010 from http://www.acen.edu.au/conferences/ACEN-2010-Proceedings.pdf.

Yorke, M. (2006). Employability in higher education: what it is - what it is not. Learning and Employability Series 1. York, UK: Higher Education Academy. 